\title{
Temas religiosos no cinema bélico soviético sobre a Segunda Guerra (1945-91)
}

\author{
Moisés Wagner Franciscon \\ Doutor em História pela Universidade Federal do Paraná (UFPR)
}

\section{Resumo}

O objetivo de promover uma análise da imagem do cristianismo e suas alterações ao longo de décadas no cenário soviético pode ser concretizado por meio de seu cinema. Os filmes soviéticos sobre a Grande Guerra Patriótica produzidos entre 1945 e 1991 indicam mudanças nos anseios sociais e posições sancionadas pelo regime à medida que a presença e a atuação da religião e de religiosos durante o conflito são reelaboradas diante das circunstâncias contemporâneas. O cinema bélico é talvez o principal gênero cinematográfico para a difusão de mensagens ideológicas - por exemplo, pela defesa do belicismo ou do pacifismo. Apesar do interesse do Estado na divulgação de sua versão da história militar, sempre é possível que o filme forneça interpretações ambíguas ou contrárias. Nos filmes de guerra sobre a Segunda Guerra Mundial afloram temas adversos à retórica oficial (como a religião) e um tratamento ainda menos consensual, como uma visão positiva da espiritualidade ou da instituição religiosa. Mais do que uma dissidência isolada de um diretor contra o Kremlin, trata-se de um fenômeno com raízes na sociedade, atingindo mesmo o partido. Emprega-se a história social do cinema, de Marc Ferro, com sua análise partindo do contexto para o filme, em busca das mensagens latentes de sua própria época.

Palavras-chave História social do cinema - Filme de guerra - Religião - União Soviética.

\begin{abstract}
The aim of promoting an analysis of the image of Christianity and its changes over decades in the Soviet scene can be achieved through its cinema. Soviet films about the Great Patriotic War produced between 1945 and 1991 indicate changes in social sentiments and positions sanctioned by the regime as the presence and performance of religion and religious men during the conflict are reworked in the face of contemporary circumstances. War film is perhaps the main cinematographic genre for the diffusion of ideological messages - for example, the defense of warmongering or pacifism. Despite the interest of the State in releasing its version of military history, it is always possible that the film provides ambiguous or contrary interpretations. In the war movies about World War II, themes that are adverse to official rhetoric (such as religion) and an even less consensual treatment emerges, such as a positive view of spirituality or the religious institution. More than an isolated dissidence of a director against the Kremlin, it is a phenomenon with roots in the society, reaching even the party. Marc Ferro's social history of cinema is employed, with the analysis starting from the context then on to the film, in search of the latent messages of its own time.
\end{abstract}

Keywords Social History of Cinema - War Film - Religion - Soviet Union. 
REVISTA ANGELUS NOVUS

Submissão

27/II/2019

Aprovação

$18 / 05 / 2020$

Publicação

I6/06/2020

\section{Introdução}

$\mathrm{E}$

ntre 1945-91 o regime soviético se viu engajado em sucessivas tentativas de normalização das relações, instrumentalização ou supressão das religiões cristãs em seu território. A própria sociedade soviética era cindida entre uma maioria ateia ou agnóstica e uma minoria de adeptos. Destes, a grande maioria era ortodoxa russa e uma minoria de católicos romanos, além de vários outros grupos menos expressivos numérica e politicamente. Ortodoxos e católicos possuíam bases étnicas, importância e imagem social discrepantes. A desconfiança com relação a uma religião estrangeira, de lideranças inimigas, não estava confinada ao Kremlin. O passado de relação conflituosa entre as duas vertentes cristãs perpassava a cultura russa e soviética (como ficou bem claro em Alexandre Nevski, 1938, de Eisenstein, película do período anterior ao analisado). A indústria cinematográfica soviética enfrentava os mesmos posicionamentos contraditórios. O Ministério do Cinema, que a financiava, o departamento da censura, externo ao ambiente de produção, e os órgãos de controle interno dos estúdios, que a fiscalizavam, e Moscou, que ditava as metas políticas, possuíam expectativas cambiantes de acordo com o momento. Os produtores almejavam seus próprios objetivos, como o reconhecimento artístico, autonomia e liberdade de expressão, e a ascensão social por meio dos bônus sobre a venda de ingressos. Diretores apresentavam suas próprias convicçóes - políticas (de engajamento pró ou contra o regime, de cooperação, convívio ou carreirismo), religiosas (ou antirreligiosas e ainda das relações dessa postura com o poder), e de identidade (soviética ou étnica-republicana, como no caso do lituano Vytautas Žalakevičius).

$\mathrm{O}$ cinema sacudiu o imaginário do século XX também por promover uma nova forma de relação com seu público ${ }^{1}$. É um dos maiores suportes da memória histórica

I "O cinema antecipou uma nova conexão, diferente daquela que havia marcado o século anterior e perceptível em uma sala de projeção: na plateia, conectada pelo mesmo projeto, interessada no mesmo objeto, os indivíduos reunidos são isolados, fechados dentro de si mesmos. Porque, focados em um objetivo fora do grupo, eles não interagem entre si. Mesmo antes do cinema houve importantes reuniões, especialmente durante cerimônias religiosas ou patrióticas, mas a missa, orando, cantando ou aclamando, [as pessoas que formam o público] intervinham ativamente no evento. Num teatro ou circo, as reações do público faziam parte da performance, a 'temperatura' da sala influenciava o julgamento dos presentes, arrastados, a despeito de si mesmos, pelo entusiasmo ou pela indiferença geral. No cinema, rodeado de vizinhos silenciosos e imóveis, o espectador forma uma opinião" (SORLIN, P. Introduzione a una sociologia del cinema. Pisa: Edizioni ETS, 2015, p.5. Tradução livre). 
coletiva das sociedades contemporâneas ${ }^{2}$. Em torno dela desenrolou-se a luta entre a memória oficial e provinda do consenso interno do PCUS (Partido Comunista da União Soviética), as memórias das várias facções do partido e do Estado ou interessantes a seus próprios projetos, a memória emergente de largas fatias da população e a memória de grupos específicos. O consenso oficial sofreu várias mudanças ao longo de décadas, apesar de manter um amplo eixo básico através de quase todo período, até ruir quase praticamente sob as reformas liberalizantes de Gorbachev. Quase praticamente porque alguns tabus não chegaram a ser rompidos, como filmes que levassem à tela as memórias e versões produzidas pelos grupos fascistas ou de guerrilheiros anticomunistas, apesar do ambiente nacionalista propício ao seu uso. Durante a Guerra Fria, o cinema foi visto pelas superpotências como mais uma arma - neste caso psicológica, angariando apoio interno enquanto pretenderia minar as forças inimigas à sua disposição3.

Torna-se difícil discordar de Youngblood ${ }^{4}$ e de sua afirmação de que a sociedade e a cultura stalinistas (e pós-stalinistas) foram muito mais dinâmicas, mesmo nos períodos de maior tensão. O que vai contra os pressupostos das teorias do totalitarismo. No entanto, é exagerada sua asseveração do belicismo soviético - comprovado pelo nascimento e morte do Estado em meio a conflitos (Primeira Guerra Mundial-Guerra Civil e Afeganistão) - como fundamento do cinema de guerra no país. Como lembra Hobsbawm', a URSS envolveu-se diretamente num número muito menor de guerras do que os EUA. E se, como Youngblood ${ }^{6}$ lembra, havia o intenso sentimento de sítio pelo inimigo externo, os filmes bélicos americanos também eram moldados pelo anticomunismo. Mais do que belicistas, as bases para os filmes de guerra soviéticos encontram-se no militarismo - não o medo das repetidas invasões sofridas ou a ameaça do expansionismo russo, mas a composição da sociedade soviética por uma fatia importante de militares ${ }^{7}$ - uma tradição anterior ao regime. $\mathrm{O}$ uso político dos temores

2 OLIVEIRA, D. “O cinema como fonte para a história”. In: Fontes históricas: métodos e tipologias, 2008, Curitiba. III Evento de Extensão em Pesquisa Histórica, 2008. pp. I-I2.

3 VIRILIO, P. Guerra e cinema. São Paulo: Scritta, I993. Ferro também aponta para o emprego do cinema como arma, ao considerá-lo como agente da história: como inovação científica, como arma militar, instrumento médico, etc. Quando os filmes viraram arte, “passaram a intervir na história como filmes, documentários ou de ficção, que, desde sua origem, sob a aparência de representação, doutrinam e glorificam” (FERRO, M. Cinema e história. Rio de Janeiro: Paz e Terra, 1992, pp. 13-I4). YOUNGBLOOD, D. Russian war films: on the Cinema Front, 1914-2005. Kansas: University Press of Kansas, 2007.

5 HOBSBAWM, E. A Era dos Extremos. São Paulo: Companhia das Letras, 200 .

6 YOUNGBLOOD, op. cit., p. 2.

$7 \quad$ Ainda no início da Era Gorbachev, havia 5,3 milhões de soldados (sendo metade deles jovens cumprindo o serviço militar obrigatório de dois anos) para uma população de 287 milhões (BARANY, Z. Democratic breakdown and the decline of the Russian military. Princeton: Princeton University Press, 2009, p. 55). No 
populares (e, sem dúvida, genuínos também na cúpula governamental) de ataques vindos de fora encontrou importante espaço de repercussão no cinema. Tal uso se configurou parcamente em material ideológico comunista e menos ainda marxista. Era largamente patriótico, nacionalista e militarista, no sentido de promover o orgulho do estilo de vida e códigos de conduta dos militares. A ideologia marxista-leninista encontrava amparo maior durante campanhas governamentais, como no imediato pósguerra ou quando a desestalinização de Khrushchev ganhou ímpeto. Em outros momentos, como na década de 1970, a inserção de mensagens estritamente partidárias, para além das boas intenções do internacionalismo para com os aliados soviéticos, foi apenas episódica. Seria mais adequado classificar o sistema soviético como uma economia de capitalismo de Estado e seu regime político como uma semioligarquia ou oligarquia incompleta ${ }^{8}$.

O caráter não-totalitário do cinema soviéticos é mais uma evidência da impossibilidade da aplicação do conceito para o próprio sistema ${ }^{10}$. Para o autor francês, os censores, "apparatchiks burocráticos - compostos por iletrados da cultura visual que julgaram a ideologia da obra por seus diálogos ou roteiro, ou seja, por seus

imediato pós-guerra a necessidade de mão-de-obra fez com que os efetivos do Exército Vermelho diminuíssem de I3 para 2.8 milhões. Com a Guerra Fria, o número de soldados permaneceu entre 4 e 5 milhôes. Durante a Guerra Civil chegou a 3 milhões de homens. Ao seu fim, eram 1,6 milhões. Durante a década de 1920 a URSS seguiu a tenência geral para a desmobilização, mantendo de 530 a 800 mil soldados (ERICKSON, J. The Soviet High Command, 1918-4I: a military-political history. London: MacMillan, 1962, p. 167). Em comparação, os Estados Unidos possuíam um exército com I8o mil soldados em 1939.

8 Rollemberg e Quadrat fornecem um apanhado das pesquisas que inserem a URSS no mundo concreto dos regimes autoritários, ou "totalizantes", como prefere Segrillo (SEGRILLO, Angelo. "URSS: coerção e consenso no estilo soviético” In: ROLLEMBERG, D.; QUADRAT, S. (org.). A construção social dos regimes autoritários: Europa. Rio de Janeiro: Civilização Brasileira, 20IO, p. I23), no qual o poder absoluto do partido encontra a necessidade de um sistema de sanções e recompensas para conquistar o apoio popular para se manter e funcionar. Os autores lembram de sua legitimidade: "A luta política contra o autoritarismo talvez tenha levado a uma superestimação das aspiraçôes democráticas dos povos, segundo a fórmula $o$ mundo marcha para a democracia. Na verdade, a história do século mostra como, não raro, o autoritarismo é que foi a reivindicação" (ROLLEMBERG; QUADRAT, op. cit., pp. I4). Ferro possui um capítulo onde expõe sua visão do sistema soviético como burocrático. Aqueles que utilizam o conceito do totalitarismo "fazem dele o pivô de seu modo de explicação da sociedade soviética, omitindo a consideração de outros dados, como, por exemplo, as disparidades regionais, o consenso que reina no país etc. Eles certamente não negam essas realidades, mas as julgam secundárias. Ou ainda, em se tratando do consenso, incluiriam de bom grado na conta (ou melhor, no débito) do povo russo e sua tradição de docilidade - como se, na URSS, só houvesse russos (...). A sociedade soviética seria então aquela cujo regime organiza o consenso, como se ela fosse a única nessa situação". Com a Revolução, iniciaram-se dois processos de burocratização: um do alto, com o controle dos burocratas do partido sobre o mesmo e sobre sindicatos e outras instituiçóes da sociedade, aparelhos de Estado, etc.; e um vindo de baixo, com as "instituições autônomas (comitês de fábrica, de bairro etc.) que se enxertou, para sobreviver, nas instituições do poder bolchevizado (...). Esse poder dispunha assim de um duplo centro, emanando, o primeiro, das instâncias dirigentes do partido e, o segundo, de instituições populares oriundas da sociedade. Seu cruzamento resultou no aparecimento de um sistema burocrático novo, uma vez que não havia solução de continuidade entre o poder político e a administração do Estado e da sociedade. Criava-se também uma situação diferente: na cúpula do sistema, o poder era irrestrito e estava nas mãos dos bolcheviques; mas na base, igualmente irrestrito, o poder pertencia coletivamente às camadas populares, bolchevizadas ou não. No meio, entre dirigentes e dirigidos, a fronteira era móvel”. Para explicar 
FRANCISCON • "Cinema bélico soviético sobre a Segunda Guerra"

componentes escritos" "i permitiam os lapsos que tornavam a narrativa e as imagens fílmicas tão reveladoras. Talvez, como o próprio autor sugere para o caso do filme da NEP Dura Lex, 1926, de Kulechov, a censura amainara não por incapacidade teórica e intelectual dos censores ${ }^{12}$, mas apesar de seu descontentamento e o do regime que, mesmo contrariados, não esboçaram reações para além do ataque pela imprensa ${ }^{13}$. Sua compreensão é a de que o cinema é uma fonte para um entre vários imaginários possíveis de uma mesma época. Não parece justa a afirmação de Kornis ${ }^{14}$ de que Ferro dirige-se para a mentalidade e Sorlin para diferentes imaginários ${ }^{15}$. Ferro percebe a expressão no cinema da luta entre diferentes visões de uma dada sociedade - a noção de contra-história baseia-se nas narrativas fílmicas de grupos que procuram desconstruir a versão oficial, dominante, da história ${ }^{16}$. $\operatorname{Kracauer}^{17}$ prevê que o cinema possa expressar a mentalidade de uma época. Ferro e Sorlin preferem enxergar a compreensão que um dado grupo possui do mundo. O confronto entre as perspectivas, representações e imaginários de diferentes grupos é tratado por Napolitano ${ }^{18}$ como uma luta entre desmonumentalizadores e monumentalizadores, entre versões laudatórias e críticas de um mesmo fato, processo ou personagem com significados divergentes para tais grupos.

esse processo, utiliza as mesmas razões que Lewin (LEWIN, M. O fenômeno Gorbachev. Rio de Janeiro: Paz e Terra, 1988, pp. 170-179): "Acumulados, desenvolvidos, esses fenômenos se acompanhavam de outras transformaçôes profundas: a escolarização, a mobilidade geográfica e profissional, a renovação quase completa do aparelho de Estado da época leninista-stalinista - salvo na mais alta cúpula. E, necessariamente, modificaram as condições da vida política". No entanto, as organizações sociais oficiais ganharam paulatinamente mais poder, responsabilidades e autonomia na década de I930. "Essa microautonomia no interior do sistema explica certamente, se associarmos ao fenômeno de pleibização analisado anteriormente, que tenha podido surgir, sobretudo na Ucrânia, certo número de obras antissemitas - e não apenas antissionistas - ou que um filme turquestano, Chakbsem et Garib, de Tahib Sabirov, apresentado todavia em um festival internacional, seja totalmente estranho à ideologia oficial. A extensão do número dessas organizações sociais no campo esportivo, cultural, etc., a multiplicação dessas áreas de microeconomia que secretam uma capacidade de agir, exercer um poder, praticar trocas inter - e micro - institucionais, constituem a marca da era de Nikita Kkrutchev e mais ainda de Leonid Brejnev". Essa autonomia coletiva era presente sobretudo na gestão municipal soviética. Em seguida, trata do conceito de polimorfismo - por exemplo, indivíduos que partilham cargos em várias esferas (membro do partido e exército ou administração). Dentro desse ambiente, é inútil pensar em disputas entre as instituições, mas sim que elas se apoiam mutuamente. $\mathrm{O}$ que não as impede de ter e aumentar suas autonomias. Os indivíduos certamente se identificam com suas instituiçôes de origem ou de carreira, mas isso não os impede de circular por outras, como o partido. Sem luta entre instituições, sobram as lutas intra-instituições - por exemplo, o uso do orçamento e objetivos estratégicos do exército, que podem encontrar colaboradores ou adversários individuais em outras instituições. Pensar que cada instituição possui representação no CC, Comitê Central do PCUS, significa reconhecer que a URSS presenciaria um pluralismo limitado - o que não é o caso. O polimorfismo a impede: "A mobilidade das responsabilidades e as passagens de uma instituição à outra são de fato uma prática constante e mais espetacular do que em outros lugares: o marechal Ustinov era civil, Brejnev era marechal e Andropov não era, na origem, 'kagebista'. Os perfis de carreira são testemunhos da realidade do fenômeno. Além disso, as divergências que essas rivalidades suscitam não são nem permanentes nem associadas a uma visão do mundo ou a um status social particular. No lugar de pluralismo ou corporativismo, utiliza a terminologia marxista-soviética para definir os efeitos desse fenômeno: ele cria "contradições não antagônicas"” (FERRO, Marc. "Há 'democracia demais' na URSS?” In: ROLLEMBERG; QUADRẢT, op. cit., citações às pp. 69; 72; 73; 75; 79; 80;81; 82). Portanto, o autor francês se opõe ao conceito de grupos de interesse e pluralismo institucional de Skilling (SKILLING, H.G. "Interest groups and communist politics revisited". In: WHITE, S., NELSON, D. (orgs). Communist politics. London: Palgrave, 1986, p. 222), aproximando-se do 


\section{REVISTA ANGELUS NOVUS}

O cinema é um dos mais poderosos instrumentos contemporâneos de monumentalização do passado, na medida em que pode fazer dele um espetáculo em si mesmo, com eventos, personagens, processos encenados de maneira valorativa, laudatória e melodramática. ${ }^{19}$

A ideia do autor, do cinema histórico como monumento em honra ao passado, certamente está imbuída do trabalho de Le Goff ${ }^{20}$. No caso do cinema soviético, a ideia de que o monumento é também uma mitologia institucionalizada ${ }^{21}$ é recorrente mesmo entre analistas críticos, que, no entanto, a alargam para todo o cinema histórico. Segundo Youngblood: “em nenhum lugar esse processo de construção e desconstrução de mitos é mais conciso e vividamente ilustrado do que no cinema" ${ }^{22}$. Youngblood possui uma percepção da utilidade da análise do cinema próxima à de Ferro ${ }^{23}$. Controlar o cinema era muito mais difícil do que a literatura. Filmes de guerra desviavam da história oficial com frequência. Todos os filmes eram políticos. Mas poucos eram apenas propaganda ${ }^{24}$. Todo filme era oficial, já que era produzido por uma estatal e com financiamento do Estado. No entanto, “é uma falácia assumir que a maioria dos filmes soviéticos não eram mais que propaganda ou que a maioria dos diretores eram meras ferramentas da burocracia cinemática do Estado”2s.

conceito de cultura política institucional como limitante do poder no regime "muito autoritário" de Brown (BROWN, Archie; SHEVTSOVA, Lilia. Gorbachev, Yeltsin \& Putin: a liderança na transição russa. Brasília: $\mathrm{UnB}, 2004)$.

9 FERRO, M. Cinema e história. Rio de Janeiro: Paz e Terra, 1992; YOUNGBLOOD, D. Russian war films: on the Cinema Front, 1914-2005. Kansas: University Press of Kansas, 2007; LAWTON, A. (org.). The Red screen. Londres: Routledge, 1992.

Io LEWIN, M. O fenômeno Gorbachev. Rio de Janeiro: Paz e Terra, I988, pp. I8-2I; Id., O século soviético. Rio de Janeiro: Record, 2006, pp. 335-336; BROWN, A. The Gorbachev Factor. Oxford: Oxford University Press, 1997; FERNANDES, L. O enigma do socialismo real. Rio de Janeiro: Mauad, 1991, pp. 24-35; SEGRILLO, A. $O$ declínio da URSS. Rio de Janeiro: Record, 2000.

II FERRO, op. cit., p. I4.

I2 "A comissão encarregada do controle dos filmes examinava apenas os assuntos, o tema, o roteiro; nem pensava em controlar a filmagem ou assistir à montagem. O filme escapava, assim, em grande parte, ao controle daqueles que, vivendo ao nível de sua própria cultura, acreditavam que, por ter lido Marx ou Stalin, era possível controlar toda a realidade num filme” (Ibid., p. 29).

I3 Ibid.; Id., “O filme: uma contra-análise da sociedade?” In: NORA, Pierre (org.). História: novos objetos. Rio de Janeiro: Francisco Alves, 1975, pp. 204-207.

I4 KORNIS, M. "História e Cinema: um debate metodológico". In: Estudos Históricos, Rio de Janeiro, vol. 5, n. IO, 1992, pp. 237-50.

I5 "É possível concluir que o reconhecimento de Sorlin da contribuição de Ferro no sentido de trazer o cinema para o campo da história, e o avanço de seus trabalhos em relação a seus predecessores, como Kracauer, não significam uma identidade com seus métodos de trabalho. Em comum, a idéia de que a imagem não copia a realidade e de que a câmera revela aspectos que ultrapassam as evidências. Entretanto, contrário ao estabelecimento de uma homologia entre filme e mentalidade de uma sociedade num dado momento histórico, Sorlin procura um sistema de leitura distinto de Ferro. Sorlin procura o auxílio da semiótica como forma de desvendar a linguagem do filme, ao passo que Ferro acaba por concentrar-se na análise contextual. A 'busca do não-visível' de Ferro está intrinsecamente ligada a uma análise do conteúdo do filme e ao contexto de produção, e muito embora remeta-se à importância da linguagem cinematográfica, parece-nos que Ferro acaba 
Algumas considerações de Chris Cagle ${ }^{26}$ sobre o cinema de Hollywood também servem para o cinema soviético. Os estúdios não produziam filmes monumentalizadores ou desmonumentalizadores apenas segundo as flutuações de poder no Kremlin e as tentativas oficiais de legitimação por novas versões do passado. Diretores e roteiristas conseguiam produzir filmes críticos, de maneira sutil, humorada ou contrabalanceando o peso das acusações ao lado de louvores, segundo as regras tácitas que permitiam que o sistema aceitasse a película. A noção de arena, encontrada em Pierre Bourdieu e E. P. Thompson, auxiliam a entender a formação e funcionamento desse jogo de interesses que moldava a indústria cinematográfica soviética. Essa disputa pode ser encontrada de maneira clara, por exemplo, em uma publicação soviética destinada ao público ocidental, que procurava equilibrar citações de diretores declarando o cinema como arte pela arte e de dirigentes, que o percebem como força para a mobilização ${ }^{27}$.

por não integrar todos esses elementos entre si. A seleção de certos aspectos que lhe parecem significativos afastam-no de uma análise dirigida à própria construção do filme e à relação sincrônica e diacrônica de seus elementos. Sorlin, por sua vez, conduz sua análise nessa direção, possivelmente em busca de maior rigor no tratamento das imagens" (KORNIS, M. "História e Cinema: um debate metodológico". In: Estudos Históricos, Rio de Janeiro, vol. 5, n. IO, 1992, pp. 237-50, citação à p. 247). Certamente Sorlin (SORLIN, P. Introduzione a una sociologia del cinema. Pisa: Edizioni ETS, 20I5) trabalha com mais atenção questões que são apenas esboçadas por Ferro (FERRO, M. Cinema e história. Rio de Janeiro: Paz e Terra, I992; Id., "O filme: uma contra-análise da sociedade?” In: NORA, Pierre (org.). História: novos objetos. Rio de Janeiro: Francisco Alves, 1975).

I6 A câmera se populariza, a sociedade toma conta das imagens e rompe seu monopólio. "Medir ou avaliar a ação exercida pelo cinema é difícil” (FERRO, M. Cinema e história. Rio de Janeiro: Paz e Terra, 1992, p. 16): pode influenciar as massas em alguns casos em que já existe um substrato ideológico semelhante, ou não vingar em seus objetivos de propaganda a não ser que faça concessões quanto a temas bem vistos. Ou então provocam reações políticas. "É preciso dizer que a utilização e a prática de modos de escrita específica são, assim, armas de combate ligadas à sociedade que produz o filme, à sociedade que o recebe. Essa sociedade se trai inicialmente pela censura em todas as suas formas, compreendendo-se aí também a autocensura” (Ibid., pp. 16-17) - ou a "censura inversa", cedendo espaço para todas as vozes, ou vozes discordantes, mas com métodos para reforçar seu próprio lado - como o uso da palavra final. "Assim como todo produto cultural, toda ação política, toda indústria, todo filme tem uma história que é História, com sua rede de relações pessoais, seu estatuto dos objetos e dos homens, onde privilégios e trabalhos pesados, hierarquias e honras encontram-se regulamentados, os lucros da glória e os do dinheiro são aqui regulamentados com a precisão que seguem os rito de uma carta feudal: guerra ou guerrilha entre atores, diretores, técnicos, produtores, que é mais cruel à medida que, sob o estandarte da Arte, da Liberdade, e na promiscuidade de uma aventura comum, não existe empreendimento industrial, militar, político ou religioso que conheça diferença tão intolerável entre o brilho e a fortuna de uns e a obscura miséria dos outros artesãos da obra" (Ibid., p. 17).

17 KRACAUER, S. De Caligari a Hitler. Rio de Janeiro: Jorge Zahar Editor, 1988.

I8 CAPELATO, M. H. História e cinema: dimensões históricas do audiovisual. São Paulo: Alameda Editorial, 2OII, p. 77.

I9 NAPOLITANO, M. "Fontes Audiovisuais: a História depois do papel”. In: PINSKY, C. (org.); et al. Fontes Históricas. São Paulo: Contexto, 20II, p. 276. 
REVISTA ANGELUS NOVUS

\section{A questão religiosa na União Soviética após a Grande Guerra Patriótica (1945-}

9I)

A religião é um elemento privilegiado para uma melhor percepção da realidade soviética. Ao contrário da imagem difundida pela propaganda anticomunista, uma importante minoria era publicamente adepta de alguma religião ${ }^{28}$. Após sua aparição na propaganda durante a guerra ${ }^{29}$, acabou eclipsada no restante dos anos 1940 e combatida no início dos 1950. Durante a gestão Khrushchev ocorreu uma grande campanha pelo fechamento de igrejas, sinagogas e mesquitas. No entanto, o cinema, às vezes, não obedecia a esta campanha, ou a criticava de maneira sutil. A exibição de manifestações religiosas em filmes de guerra e a crítica às políticas oficiais para a religião ganharam impulso nos anos Brejnev. A imagem da relação dos combatentes e da população civil com a religião mudou ao longo do tempo. A política do regime para com as religiões organizadas transitou entre fases de coexistência, combate e pragmatismo utilitarista. É importante notar que, para as massas, tampouco o cenário religioso foi cristalizado. Existiram importantes ondas sociais de revitalização do culto religioso, e outras de afastamento, secularização e ateísmo. Nos anos após a Revolução, a importância da

2I Dobrenko, adepto do conceito de totalitarismo, também menciona essa característica. Para ele, filmes como Alexandre Nevski consagraram uma religião secular de Estado, que segue os moldes da tradição ortodoxa para divinizar o líder. Cita ainda o crítico Valery Podoroga para afirmar a função privilegiada do cinema para a assimilação popular da mitologia oficial e dos estereótipos ideológicos (DOBRENKO, E. Stalinist cinema and the production of history: museum of the revolution. Edimburgo: Edinburgh University Press, 20o8, pp. 74; 23). Posição compartilhada pelo mitólogo russo-soviético Eleazar Meletínski ao afirmar que "o tempo da revolução comunista é o tempo mitológico” (MELETÍNSKI, Eleazar. "Harmonia mítica com o cosmos” In: BERNARDINI, A.; FERREIRA, J. (orgs.). Mitopoéticas: da Rússia às Américas. São Paulo: Editora Humanitas, 2006, p. 54).

22 YOUNGBLOOD, Denise. "Ivan's Childhood (USSR, 1962) and Come and See (USSR, I985): Post-Stalinist Cinema and the Myth of World War II" In: CHAMBERS II, J. W.; CULBERT, D. World War II, Film, and History. Nova York: University Oxford University Press, 1996, p. 85.

23 Filmes de guerra "são uma notável fonte para o estudo da sociedade e política soviéticas. Filmes de guerra possuem o potencial para reforçar ou minar as estórias do partido sancionadas pelo Estado buscadas pelos cidadãos para ouvir sobre seu passado. Mais importante, contudo, filmes de guerra forneceram um espaço altamente disputado para suportar ou desafiar visões oficiais da história soviética. Alguns eram de fato ferramentas úteis de persuasão política, mas muitos outros eram muito mais que isso" (Id., Russian war films: on the Cinema Front, 1914-2005. Kansas: University Press of Kansas, 2007, p. 3. Tradução livre).

24 Como é, por exemplo, a posição de Kenez (KENEZ, P. Cinema and Soviet Society, I9I7-I953. Cambridge: Cambridge University Press, I992, p. I87) ao comparar a produção de filmes - ou propaganda - da URSS com a da Alemanha nazista. Dos 1,363 filmes produzidos nos I2 anos de regime nazista, os censores americanos baniram apenas 208. Já os soviéticos teriam produzido apenas 70 ou 80 filmes apolíticos, como gravações de concertos e romances czaristas. Reforça sua posição com a lembrança de que ao fim da guerra capturaram alguns filmes nazistas e os distribuíram internamente. Kenez não diz quantos, mas os trofeinye filmy, filmes troféus de guerra, capturados na UFA (Universum Film Aktien Gesellschaft, Filmes Universum Sociedade Anônima. O maior estúdio da Alemanha dos anos 1920-40) em Neubabelsberg, eram constituídos por 33 filmes alemães, 3i filmes americanos, cinco italianos, um tchecoslovaco e um britânico (BILTEREYST, D; VANDE WINKEL, R. Silencing cinema. Londres: Palgrave, 20I3) - o que, para o autor, significa que o melhor método para estipular o que é filme de entretenimento ou arte e o que é filme de propaganda é o parecer de 
FRANCISCON • "Cinema bélico soviético sobre a Segunda Guerra"

religião decresceu, como nos anos 1950-6o. Durante e após a Segunda Guerra, bem como a partir dos anos 1970, a influência religiosa passou a reconquistar terreno.

Havia poucas centenas de igrejas abertas e em funcionamento até a guerra. Em abril de 1946 já eram I0,544 e em janeiro de $1949,14,477^{30}$. A partir da segunda metade de 1954, o Comitê Central sentiu-se incomodado com o revival religioso. O considerava uma ação imperialista de infiltração, um fracasso das campanhas ideológicas oficiais, da adesão ao regime e uma forma de enfraquecimento econômico: a população se ausentava do trabalho em dias santos que não constavam como feriados no calendário oficial, peregrinações individuais ou em grupos a lugares sagrados resultavam em absenteísmo ainda maior; as festas religiosas seriam apenas uma desculpa para embriagar-se, entre os cristãos, e abater o rebanho tão necessário para a recomposição do setor agrícola - prática cristã e islâmica. Além disso, a resolução do partido queixavase do obscurantismo dos religiosos frente à ciência e a educação no país, e de seus sacrifícios, entendidos como crueldade contra os animais. Temia-se a ameaça de uma união de forças nacionalistas e religiosas, quando ambas coincidiam, como o catolicismo lituano e ucraniano, o catolicismo ortodoxo grego ucraniano, o islamismo centro-asiático, o budismo nas fronteiras orientais, os seguidores das igrejas armênia e

um burocrata militar americano em sua zona de ocupação alemã na Guerra Fria. Entre 1942 e 1945, dos I500 filmes longas-metragens feitos nos EUA, mais de 800 diziam respeito à Segunda Guerra (URWAND, B. $A$ colaboração: o pacto entre Hollywood e o nazismo. São Paulo: LeYa, 20I4, p. 252). Esse número certamente subiria muito se fosse agregado ao das curtas-metragens para crianças, além de vídeos de treinamento, publicidade de bonds, etc.

25 YOUNGBLOOD, D. Russian war films: on the Cinema Front, 1914-2005. Kansas: University Press of Kansas, 2007, pp. 3-5.

26 "Por que, exatamente, os grandes estúdios contrataram artistas de esquerda e financiaram projetos com conteúdo de esquerda? A historiografia sobre o período tende a assumir a perspectiva de indivíduos que, compreensivelmente, se irritaram com as limitações de seu trabalho e de suas políticas. No entanto, esse foco no artista expõe apenas metade do jogo social; em vez de ver os produtores e os estúdios como um obstáculo para os roteiristas e diretores de aluguel, pode-se perguntar em que condições cada um compartilhava metas. A partir dessa perspectiva explicativa, a história da mídia explica não apenas a agência individual, a estrutura institucional ou o ambiente econômico, mas também a coordenação ou divergência de interesses sociais" (CAGLE, Chris. "When Pierre Bourdieu Meets the Political Economists: RKO and the Leftists-in-Hollywood Problematic” In: STAIGER, J.; HAKE, S. Convergence, media, history. Milton Park: Routledge, 2009, p. 24. Tradução livre). Cagle responde à questão com a exposição de dois processos simultâneos no cinema americano dos anos 1940: a transformação econômica dos estúdios e, utilizando Bourdieu, a existência de um campo de produção cultural, que valoriza aqueles que produziam filmes de qualidade.

27 O livro traz uma citação do premiê Leonid Brejnev: "a arte do cinema tem uma tremenda força de impacto nos coraçóes e mentes de milhões. Isso é muito importante para fazer essa força servir a grande causa do humanismo, progresso social, e o enriquecimento espiritual e moral do homem. Os trabalhos talentosos da literatura e da arte são parte do patrimônio nacional” e, entre outras, uma de Tarkovsky: "o artista começa no ponto em que, nessa concepção ou mesmo no próprio filme, sua própria estrutura de imagem e sistema de pensamento sobre o mundo real emergem e ele os submete ao veredicto do público como seus sonhos mais queridos. Somente tendo sua própria visão e tornando-se uma espécie de filósofo, ele se torna um artista e o cinema - uma arte" - duas visões opostas sobra a função da arte - ou sobre se ela deve ter função (COMITÊ ESTATAL DE CINEMA DA URSS. Soviet Cinema. Moscou: Planeta Publishers Moscow, 1979, pp. I03; I78. Tradução livre). A tensão entre as expectativas políticas e artísticas perpassa o livro, dividido entre o cinema intelectual e o cinema de massa, findando com um documentário sobre líderes comunistas - entre eles o 


\section{REVISTA ANGELUS NOVUS}

georgiana. Havia o sentimento de que se havia perdido o controle sobre o espírito da população, e que era necessário reavê-lo. A campanha ateísta foi renovada: agora menos agressiva do que nos anos 1920-30. Alguns jornais incorporaram-se à campanha, como o Trud [Trabalho] e o Literatura i jizn [Literatura e vida]. Não era conduzida apenas por Khrushchev, mas por outros políticos destacados, como os ideólogos Suslov e Ilichev, além do presidente do Conselho para Assuntos da Igreja Ortodoxa Russa, Kuroedov. Em agosto de 1959 o Pravda apresentou um editorial no qual diferencia o direito da liberdade de consciência da propagação impune de religiões estranhas ou contrárias aos interesses dos trabalhadores ${ }^{3}$.

Tal campanha, no entanto, não foi endossada por todas as facções do partido. Simonov conseguiu espaço na ateísta Nauka i religiya [Ciência e religião] para publicar seu artigo de 1963 em que apontava para a "verdade moral e a beleza moral" de passagens da Bíblia ${ }^{32}$. Existia uma entidade que fiscalizava a todas as denominações religiosas do país, dos ortodoxos aos budistas: o Conselho de Assuntos Religiosos. A maior ferramenta de Khrushchev foi o fechamento de templos: havia 22,00o igrejas ortodoxas em 1959, 13,008 em 1960 e 7,873 em 196533. Existiam 2,455 igrejas georgianas em 1917, e cerca de I0o em 1962 (sendo II na capital Tbilisi). As 25,000 mesquitas em 1917 caíram para 500 na década de 1970. De oito seminários, cinco foram fechados. O número de seminaristas caiu de 396 em 1953 para 70 em 196I. Os seminários foram

próprio Brejnev - e um texto do secretário-geral.

28 Em 1984 os números eram: I8\% da população era de ortodoxos russos, $9 \%$ de muçulmanos, 3\% de judeus, protestantes, ortodoxos georgianos e católicos romanos. Os ateus somavam 70\% da população (ESTADOS UNIDOS DA AMÉRICA; CIA. The world factbook 1984. Washington: US Government Printing Office, 1984, p. 209). Em 1990, em meio ao renascimento religioso e a emigração acelerada dos judeus para Israel, os números eram: $20 \%$ era ortodoxa russa, IO\% muçulmanos, I\% judeus (ESTADOS UNIDOS DA AMÉRICA; CIA. The world factbook 19go. Washington: US Government Printing Office, 1990). Em 1987 há ainda os seguintes dados: $70 \%$ de ateus, I8\% de ortodoxos, $9 \%$ da população da Ásia Central seriam muçulmanos (ALMANAQUE ABRIL 88. São Paulo: Abril, 1988, p. 445).

29 Na década de 1920 , além da ampla campanha antirreligiosa, o regime pretendeu ou estabelecer algum controle sobre as instituições religiosas ou criar lideranças internas às fronteiras soviéticas, mas suscetíveis de vigilância. $\mathrm{O}$ arcebispo Aleksandr Vvendeskii, um dos criadores do movimento renovacionista, ou obnovlentsy, acabou recebendo o respaldo do regime para pregar sua versão social e igualitária dos Evangelhos, ainda na década de 1920 (MINER, S. Stalin's Holy War: religion, nationalism, and alliance politics, 194I-1945. Chapel Hill: University of North Carolina Press, 2003, p. 2I). Tal concepção era vista como progressista pelas autoridades. Apesar dos esforços, os setores tradicionalistas da Igreja Ortodoxa jamais admitiram a expansão dessa interpretação bíblica progressista. Em 1985, o Metropolitano de Kiev e Galícia afirmava que os católicos adeptos da Teologia da Libertação na América Latina cometiam erros acerca da fé (RAMET, S. Religious Policy in the Soviet Union. Cambridge: Cambridge University Press, 2005, p. II4).

30 ANDERSON, J. Religion, State and Politics in the Soviet Union and successor States. Cambridge: Cambridge University Press, 1994, pp. 9-16.

3I ANDERSON, J. Religion, State and Politics in the Soviet Union and successor States. Cambridge: Cambridge University Press, 1994, p. 19.

33

STANLEY, B. Christianity in the Twentieth Century. Princeton: Princeton University Press, 2018, p. 94.

$278 \cdot$ ano XI, n. 16, 2020 • ISSN 2179-5487 
reduzidos de 69 em 1959 para 17 em 1965. O número de popes caiu de 30,000 para 6,180. Em 196I foram proibidos os serviços religiosos fora dos templos, sem permissão das autoridades - o que significava procissões, peregrinações e festas ${ }^{34}$. Foi proibido soar os sinos dos campanários. O Conselho de Kuroedov poderia impedir o exercício do sacerdócio a elementos considerados perigosos.

Com Brejnev, a campanha se extinguiu. Porém os templos foram reabertos com maior morosidade do que no pós-guerra stalinista: 40 igrejas ortodoxas entre 1977-8335. Se na era Khrushchev o proselitismo poderia resultar em detenção, sob Brejnev apenas líderes incômodos foram reprimidos. Algumas publicações religiosas foram impressas em editoras oficiais do Estado ${ }^{36}$. As clandestinas continuaram ilegais. A disseminação do sentimento religioso em importantes fatias da sociedade, que atingia até grupos do partido, chegou também ao cinema. Se as mençóes à religião geralmente eram utilizadas de maneira ambígua pelos diretores no fim dos anos 1950, tornam-se menos sutis e emaranhadas com o nacionalismo ucraniano ou russo. Em 1978, para os festejos do ducentenário de Tolstoi, o diretor Igor Talankin trouxe à cena uma adaptação do romance Pai Sergio, contando com bom orçamento e atores importantes, como Sergey Bondarchuk no papel do protagonista. A primeira adaptação, feita por Yakov

Tal lei, no entanto, era comumente desobedecida pela população, como Benami (BENAMI, A. Entre a foice $e$ o martelo. Rio de Janeiro: Bloch, 1968) demonstra involuntariamente ao descrever grupos de milhares de judeus no exterior das raras sinagogas durante cultos em dias santos, e o uso pelos rabinos de alto-falantes para absorver a multidão no ofício religioso - o que seria impensável no restrito espaço físico interno.

RAMET, S. Religious Policy in the Soviet Union. Cambridge: Cambridge University Press, 2005, p. 26.

36 Benami aponta vários outros direitos da Igreja Ortodoxa: os livros editados pelas impressoras estatais seriam muitos, incluindo liturgias e livros de culto; mantinha sua estrutura hierárquica, controlando e se comunicando com as diversas paróquias a partir de sua sede em Zagorsk - uma rede paralela às oficiais. "Os chefes da Igreja Ortodoxa são convidados a participar de várias cerimônias oficiais, e, quando isso convém aos interesses do Governo central, fazem sua aparição, com toda a pompa habitual, nos coquetéis das embaixadas em Moscou. Além disso, permite-se a esses eclesiásticos que viajem para comparecer a convenções de sua igreja ou a convenções interconfessionais em todas as partes do mundo" (BENAMI, A. Entre a foice e o martelo. Rio de Janeiro: Bloch, I968, p. 59), em troca de se tornarem verdadeiros agentes do regime interna e externamente - ideia também defendida por Labin (LABIN, S. A Rússia de Stalin. Rio de Janeiro: Agir, 1947). Ramet (RAMET, S. Religious Policy in the Soviet Union. Cambridge: Cambridge University Press, 2005), exibe um relacionamento de duas vias com o Kremlin, incluindo o uso da tribuna numa conferência internacional para a paz para condenar as pressões de Khrushchev sobre a prática religiosa visível, como as celebrações fora dos templos. Benami aponta para a existência de relacionamentos mais ou menos "frutíferos" entre líderes religiosos e o Estado. Os bem-comportados armênios seriam aqueles que desfrutariam dos maiores privilégios. Sua sede, em Esmiayin, seria luxuosa, cercada por mosteiros e igrejas em ótimas condições. "O Governo estimula a peregrinação ao Centro religioso e espiritual em todos os cantos da Terra [os armênios da diáspora]. Dezenas de milhares de armênios chegam a Esmiayin trazendo oferendas e presentes. Do mesmo modo, as autoridades veem com bons olhos o envio de contribuições em dinheiro ou em valores, feitas de todos os cantos da diáspora armênia ao centro religioso. Tenho a impressão de que a única loja 'privada' que existe na União Soviética é aquela que o Católico armênio abriu em Erivão [a capital], com autorização do Governo, onde é vendida toda espécie de presentes recebidos do exterior, principalmente objetos de consumo e vestuário (...). Assim são as coisas, quando o Governo considera que há razões não só para tirar proveito da conservação da estrutura eclesiástica existente, como também para desenvolvê-la para uso de um setor religioso nacional, disperso por várias regiões, cujo centro espiritual acha-se dentro do território soviético" (BENAMI, op. cit., p. 62). 


\section{REVISTA ANGELUS NOVUS}

Protazanov, em 19I8, fora duramente criticada pelo regime na época. O filme - como o romance de Tolstoi - permite críticas à religião organizada e ao czarismo, mas não à espiritualidade.

\section{Ortodoxos}

A influência vinda de baixo para a reabilitação da religião fez-se sentir durante e após a guerra. Este renascimento religioso chegou à literatura e poesia com o Degelo ${ }^{37}$. Pasternak publica poesias religiosas ou de tema religioso. Menções a Deus e à religião em obras publicadas. Alguns autores se referem ao período como o do ressurgimento do messianismo russo, com o retorno do discurso das três capitais do Cristianismo e Moscou como a última destas, e também do socialismo ${ }^{38}$. Tendências ligadas ao passado - ou a uma visão contemporânea do passado - autoritário, religioso, e chauvinista russo podem ser captadas nas obras literárias de Solzhenitsyn, publicadas na URSS antes de sua expulsão ${ }^{39}$. Durante o fim dos anos 1960 e a década de 1970 a pressão da Igreja Ortodoxa e dos grupos sociais praticantes permitiram não só o recuo das políticas que foram hegemônicas na segunda metade dos anos 1950 e primeira dos anos 1960, como a conquista de direitos abolidos ainda durante a Revolução de Outubro ${ }^{40}$. Um novo consenso político e social sobre o papel da religião organizada emergiu. Ao menos para a Igreja Ortodoxa.

Em julho de 1945 o regime recebera 5,770 petições públicas para a reabertura de igrejas, das quais $4 \mathrm{I} 4$ foram atendidas, 3,850 recusadas pelos sovietes locais e 1,506 aceitas em agosto ${ }^{4}$. Os cinejornais soviéticos durante a guerra apresentaram imagens de fieis

37 No cinema, Labarrère (LABARRÈRE, André. Atlas del Cine. Madrid: Akal, 2009, p. 342) o chama de sobressalto e estipula que esta fase durou entre 1954 e 1959, até o início da Nova Onda dos anos 1960. Como os demais autores, lembra que o período se iniciou com o romance $O$ degelo, de Ilya Ehrenburg, no início de 1954. A descrição de um ambiente de trabalho despótico era uma crítica clara ao stalinismo. As artes, em especial o cinema, a literatura, a poesia e o teatro, deram apoio às políticas de desestalinização. Além das críticas políticas, também se distinguiu por novas linguagens e pela reforma do realismo socialista.

38 MEHNERT, K. O Homem Soviético. São Paulo: Boa Leitura, 1966, pp. 256-257; 277-278.

39 CLAUDIN, F. A oposição ao "socialismo real". Rio de Janeiro: Marco Zero, 1983, p. 5I.

40 Em janeiro de 198I, o clero requalificou-se em sua condição tributária de ser taxado como um empreendimento comercial privado (como era antes) para ser taxado como igual àquele da prática privada médica ou dos educadores privados. Essa nova legislação também concedia ao clero direitos iguais de propriedade e herança, bem como os privilégios concedidos aos cidadãos se fossem veteranos de guerra. À organização paroquial leiga de 20 pessoas que possuíam a paróquia foi concedido o estatuto de uma pessoa coletiva com os seus direitos adequados e a capacidade de fazer contratos (a igreja tinha sido privada deste status por Lenin em 1918). Pela primeira vez em muitos anos, as sociedades religiosas poderiam legalmente possuir suas casas de culto (POSPIELOVSKY, D. Soviet antireligious campaigns and persecutions. Basingstoke: MacMillan Press, 1988, p. 120).

4I MINER, S. Stalin's Holy War: religion, nationalism, and alliance politics, 194I-1945. Chapel Hill: University of North Carolina Press, 2003, p. 147.

$280 \cdot$ ano XI, n. I6, 2020 • ISSN 2179-5487 
ortodoxos que faziam suas preces a Deus e também ao sucesso do poderio militar do país. Ganharam espaço cenas com anciãs persignando-se e aos soldados que marchavam para o front. A posse do patriarca eleito, Alexy I, em fevereiro de 1945, contou com a cessão de parte da mídia (radiodifusão) pelo Estado. A presença da Igreja nos meios de comunicação arrefeceu lentamente. No entanto, posturas ateístas e críticas à instituição nos filmes, como fora norma nos anos 1920 e em menor proporção à medida que os anos 1930 transcorriam, desapareceram. Não há menções claras à Igreja e ao culto ortodoxo nos filmes selecionados produzidos durante o pós-guerra e os anos finais de Stalin. Ao menos no gênero do filme bélico, predominava a ignorância de sua existência. São raras as ocasiões, como em Povest o nastoyashchem tcheloveke [A história de um homem de verdade], 1948, dirigido por Stolper, baseado na novela do escritor e deputado Boris Polevoi, em que se pede as bênçãos de Deus para a recuperação da saúde - o que, segundo Mehnert42, era uma expressão sem uma necessária conotação religiosa ${ }^{43}$. Para se encontrar referências à Igreja Ortodoxa é necessário mudar de gênero fílmico. São os épicos históricos que trazem personagens e situações relacionadas à religião da maioria dos eslavos. Se Eisenstein enfrentou a censura em meados dos anos 1930 ao preencher seu $O$ prado de Bejin com temas religiosos e tratar da dessacralização forçada de igrejas, seu Alexandre Nevski, no fim da mesma década não mencionar a santidade do personagem - apesar de o templo ortodoxo dominar o perfil da cidade -; ao fim da Segunda Guerra, seu Ivã, o Terrivel, elogiado e premiado pelo regime, traz a sagração de um monarca rodeado por clérigos, segundo a tradição cristã russa. A religião, apesar de não atacada no pós-guerra, é entendida pelo regime como algo do passado.

A política de aproximação com a Igreja foi invertida durante os anos Khrushchev. O natal de Na semi vetrakh [Nos sete ventos], de 1962, é um natal leigo, com a árvore, Pai Granizo e outras decorações sem expressão religiosa. Como muitos outros filmes não só do cinema dos anos do novo líder do Kremlin. Apesar das campanhas oficiais de ateísmo e de dessacralização das igrejas de menor porte, sua representação permaneceu na obra de alguns cineastas. Em O destino de um homem, de 1959, produzido por Sergei Bondarchuk, sobre o livro de Mikhail Chólokhov, os prisioneiros soviéticos encontram abrigo dentro de um templo ortodoxo. O diretor poderia escolher qualquer lugar

\footnotetext{
42 MEHNERT, K. O Homem Soviético. São Paulo: Boa Leitura, 1966.

43 A frase é dita por Stepan Ivanovich (Vasily Merkuriev) ao comissário Vorobyev (Nikolay Okhlopkov). O comissário do partido cumpre a função de reavivar a fé de Alexey Meresyev (Pavel Kadochnikov) em si mesmo e em seu futuro - exatamente o mesmo alento espiritual que se espera de uma figura religiosa. A absorção pelo partido desse papel é mais um indício de que a frase não possui conotação religiosa concreta. Um chavão vazio de significado.
} 


\section{REVISTA ANGELUS NOVUS}

amplo para o repouso dos homens: uma escola, uma sede local do partido. Porém as imagens internas e externas mostram claramente uma igreja. O que o filme não indica é se ao templo encontrava-se em ruínas pelo ataque alemão ou pelo descaso pósrevolucionário. Exibir um espaço sagrado como um refúgio não era exatamente obedecer às ordens emanadas recentemente dos novos mandatários do Kremlin. O diretor, no entanto, estabelece elementos que permitem uma segunda leitura: o local é também uma prisão a serviço do inimigo, e aqueles que tentarem escapar serão mortos.

Um soldado aperta o crucifixo no peito e ora por proteção divina. Na igreja, persigna-se até em decorrência dos trovões - um indicativo de pode ser visto também como uma imagem do atraso. Mais ainda se contraposto ao personagem médico - este recebe primeiros planos com o rosto iluminado. Aquele, em penumbra. Seus preconceitos religiosos o levam a ser morto pelos alemães, ao tentar se ausentar da igreja. Num panorâmico horizontal, o rosto hierático dos soldados perplexos com a morte confunde-se com os rostos dos anjos nos mosaicos e afrescos. A passagem dos prisioneiros de guerra pelo campo santo encimado pela igreja, no formato de um vale coberto por cruzes, poderia ser uma referência ao Salmo 23. Bondarchuk inseriu elementos que permitem que os segmentos antirreligiosos se identifiquem com a história, bem como os contrários às novas diretrizes governamentais.

Um dos campeões de bilheteria de 1963, ainda na era Khrushchev, foi o filme de guerra Troe sutok posle bessmertiya [Três dias depois da imortalidade], de Vladimir Dovgan. O título traz uma referência explicitamente religiosa, comparando o sacrifício dos soldados de Sebastopol, numa luta até o mar que durou quatro dias, com a ressureição de Cristo. Os jogos de claro-escuro do diretor, iluminando os rostos dos soldados nos túneis sob a cidade, lembram a iconografia religiosa e o futuro trabalho de Larisa Shepitko em $A$ ascensão [Voskhojdeniie].

Antigos hábitos são mostrados em $V$ boy idut odni stariki [Apenas os velhos estão indo para a batalha], de 1973. O maestro Titarenko (Leonid Bikov), comandante do Segundo Esquadrão “cantante”, reclama do comportamento do mecânico Makarych (Aleksei Smirnov), que persigna os pilotos e avióes:

Titarenko - Makarych.

Makarych - Sim.

Titarenko - O rumor no quartel-general de Hitler é que alguns dos ases soviéticos são abençoados com o sinal da cruz antes da batalha por alguns mecânicos inconscientes politicamente.

Makarych - Há muita fofoca no exército de Hitler. ${ }^{44}$

44 V boy idut odni stariki [Apenas os velhos estão indo para a batalha]. Direção: Leonid Bikov. Kiev: Dovjenko Kinostudiya, 1973. I DVD (92 min), P\&B.

$282 \cdot$ ano XI, n. $16,2020 \cdot \mathrm{ISSN} 2179-5487$ 
Assim que ajuda o piloto a colocar o paraquedas e o gorro, e este sobe a carlinga da aeronave, o mecânico o persigna pelas costas rapidamente, seguido por um gesto que expõe sua conduta considerada inadmissível. Ambos entendem que uma reprimenda deve ser dada em mensagem cifrada. As acusações partem do QG de Hitler e não dos companheiros da esquadrilha; há muita fofoca no exército de Hitler e não entre a tropa soviética. O público pode optar por uma compreensão de repressão do regime contra a religião, do cotidiano de sigilismo e da dualidade do comportamento social e público e privado ${ }^{45}$, ou pode entender o uso da benção como uma superstição risível do personagem cômico, como em outra cena na qual o mecânico pretende abençoar uma aeronave. Ao perceber que se tratava de um aparelho capturado, ainda com a suástica na cauda, interrompe sua benção e cospe. Como abençoar o piloto soviético num avião nazista? Aleksei Smirnov (Makarych) era um ator de filmes de humor imensamente popular por seu jeito bonachão e desajeitado. Já havia contracenado com Yuriy Nikulin em Operatsiya ' $Y$ ' i drugie priklyucheniya Shurika [Operação Y e outras aventuras de Shurik], um dos maiores sucessos de bilheteria na URSS. Novamente, a escolha do personagem e do ator isentam a direção de críticas das agências de censura. Smirnov era um herói de guerra condecorado, um sargento de artilharia que combateu entre 194I e 1945 - portanto, também um sobrevivente; também músico amador no campo de batalha ${ }^{46}$. O filme ucraniano contou com dois produtores, Nikolay Zlochevsky e Ilya Fidman. O diretor e ator Bikov foi auxiliado por dois roteiristas para produzir o script, Yevgeni Onopriyenko e Aleksandr Satsky.

Não foi apenas o nacionalismo ucraniano que se ligou a temas religiosos. O russo também. Um exemplo é Sudba [Destino], 1977, de Evgeny Matveev. O filme une os elementos nacionalistas russos do alto stalinismo a imagens ortodoxas. A partida dos conscritos e voluntários para o front se torna uma procissão, aparentemente em direção ao templo da aldeia. O protagonista Derugin, antes de ser capturado, entra em um delírio no qual relaciona elementos religiosos com a resistência às forças estrangeiras (bem caracterizadas pelo capacete morion, surgido na Espanha e disseminado pela Europa durante os séculos XVI e XVII - provavelmente em referência às Guerras da Livônia ou à Guerra Russo-Sueca de Boris Godunov). As cenas, por mais enfaticamente religiosas, também podem receber uma leitura crítica: as massas precisam ser despertas pelo sacrifício individual e nacionalista, passando da esperança espiritual para a ação concreta.

45 BROWN, A. The Gorbachev Factor. Oxford: Oxford University Press, 1997.

46 Smirnov ganhou as medalhas Ordem da Glória de 2o e $3^{\circ}$ grau, a Ordem da Estrela Vermelha, Por Coragem e Por Mérito Militar (PEOPLES.RU. Alex Smirnov. [online] «http://www.peoples.ru/art/cinema/actor/alex_smirnov». Acessado em I3/I2/20I7). 


\section{REVISTA ANGELUS NOVUS}

Em 1978 Chukhrai dirigiu Tryasina [Lama], filme do qual foi também o roteirista, juntamente com Viktor Merejko. Uma mãe, Matryona (Nonna Mordyukova ${ }^{47}$. Matryona relaciona-se com o próprio termo mãe, mat), que acredita ter perdido seu primeiro filho convocado para o exército resolve esconder o filho mais novo durante um bombardeio, logo após sua conscrição, e dá-lo como morto para as autoridades. No entanto torna-o prisioneiro no sótão por deserção, caso saia de sua cela. Batizada, desesperada pela situação em que colocou o filho, decide confessar-se ao pope local (Ivan Ryjov). Diante da pena prevista e do receio que paira sobre a sociedade, alguns segredos não podem ser revelados mesmo sob o sigilo do sacramento. O que exaspera o sacerdote tirado de seu almoço. Matryona compara-se com Maria. Jesus não poderia ter sido salvo? Ou este ao menos não era seu desejo? O que ela poderia ter feito para salvar o filho caçula? - que todos dão por morto. O padre a acusa de tentar a Deus. Cristo morreu para salvar os pecadores. E o filho de Matryona "morreu por uma causa justa para o povo". Sua traição não seria endossada mesmo pela Igreja, em comunhão com o patriotismo oficial. A cena do confessionário seria difícil de imaginar sob Stalin ou Khrushchev. A menos que a mãe fosse definitivamente descrita como uma criminosa, e não também como uma mãe... seguindo o humanismo característico do diretor que foi um dos pais do cinema do Degelo. Os sentimentos religiosos combinados com o nacionalismo russo, ambos em ascensão na década de 1970, vão ainda mais longe.

Em Front bez flangov [Frente sem flancos], de 1975, de Igor Gostev, baseado na novela de Semyon Tsvigun, que também foi roteirista, o pope Pavel (Ivan Pereverzev) procura enterrar todos os mortos de uma unidade regular cercada pelo inimigo (que brevemente se converteria em grupo partisan). Petrenko (Aleksey Borzunov) - que, apesar de ucraniano, não era o único na tropa - faz choça da tentativa. O sacerdote lembra que aqueles que estão mortos são heróis, que não fugiram de suas responsabilidades, como os vivos - incluindo aí Petrenko. Irritado, o acusa de falar demais. O que não era uma incriminação sem repercussões. Enquanto Petrenko tornarse-ia um traidor e colaborador nazista, o religioso se apresenta ao oficial do NKVD (Narodnyy komissariat unutrennikh del, Comissariado do Povo para Assuntos Internos, antecessor do KGB) Mlynski (Vyacheslav Tikhonov), pedindo uma arma e disposto a abandonar a vocação. A reação do militar é convencê-lo a permanecer numa função mais útil ao esforço de guerra soviético:

47 A escolha de Mordyukova para o papel suscita algumas dúvidas. Teria sido, como aponta Rollberg (ROLLBERG, P. Historical dictionary of Russian and Soviet cinema. Lanham: Scarecrow Press, 2009, p. 465) pelo contraste com seu papel de revolucionária que abandona a maternidade em Kommissar, Filme de 1968 ? Ou pela semelhança da atriz veterana com o cartaz $A$ pátria mãe chama, o que geraria um confronto com a iconografia oficial e patriota, como afirma Youngblood? (YOUNGBLOOD, D. Russian war films: on the Cinema Front, 1914-2005. Kansas: University Press of Kansas, 2007, p. 174). 
FRANCISCON • "Cinema bélico soviético sobre a Segunda Guerra”

Mlynski - Obrigado, Pavel Ivanovich. Mas as armas podem ser mais do que apenas o rifle.

Pense nisso. As pessoas com medo estão confusas pela guerra. Sua ajuda não será desnecessária.

Terá que cuidar dos fracos. Esconder os fiéis do inimigo. Você pode ajudar mais do que o rifle.

À sua porta vão bater pessoas diferentes. Alguém pode enviar uma mensagem para nós. Você aceita isso? ${ }^{48}$

Em tese, o papel de proteger os fracos seria fundamentalmente do partido, que seria dono também da principal ferramenta para a firmeza ideológica e moral contra as forças inimigas, política e não espiritual, científica e não religiosa. O religioso persigna o major pelas costas (Gostev permite a saída de Mlynski do enquadramento, fechando a câmera sobre Pavel num plano americano. A benção se torna indireta, e a cena, menos contundente), que está longe de ser o comandante orgulhosamente ateu do passado.

O diretor excita a imaginação do público. No gabinete dos oficiais nazistas, o Coronel-general von Horn (Hannyo Hasse, ator alemão oriental) recebe os relatórios da atividade guerrilheira e "terrorista" de pequenos grupos. O ordenança o informa (e a plateia) da presença de um padre. Pavel se apresenta a rigor, com a batina e o grande crucifixo no peito. Existiriam dois Pavel? Um, aparentemente próximo ao povo em seus modos, e outro aparatoso? Um patriota soviético e um colaborador nazista? Um exemplo do comportamento dúbio e indigno de confiança da Igreja durante a guerra? Queixa-se ele da ocupação do templo por soldados alemães. Von Horn o lembra que isso é para seu bem, já que os alemães lutariam “por ele”. Pede a ele pela reabertura do santuário, que "acalmaria” a população com a pregação religiosa. Ao concordar, Pavel aclama o coronel-general como "verdadeiro cristão".

Von Horn - Diga-me, pai... Me diga... Sinceramente... Você é um adulto. O que está acontecendo? Nós viemos liberá-lo da tirania dos bolcheviques, mas não entendemos a população. Não recebemos apoio suficiente e simpatia. Qual é o problema? Não tenha medo. Diga-me a verdade.

Pai Pavel - Pode um homem contar toda a verdade?

Von Horn - Bom. Diga sua verdade.

Pai Pavel - A guerra trouxe-nos problemas e ruína, morte para milhares de pessoas. As lágrimas e o pranto vieram em nossas casas. Deus vê tudo!

Von Horn - Deus está sempre do lado dos vencedores.

Pai Pavel - Mas misericórdia, senhor General, é um dos mandamentos de todas as religiôes.

Von Horn - Calma - este é o mandamento básico para as pessoas vitoriosas. ${ }^{49}$

48 FRONT bez flangov [Frente sem flancos]. Direção: Igor Gostev. Moscou: Mosfilm, 1975. 2 DVDs (I70 min), color.

49 FRONT bez flangov [Frente sem flancos]. Direção: Igor Gostev. Moscou: Mosfilm, 1975. 2 DVDs (17o min), color. 


\section{REVISTA ANGELUS NOVUS}

A maior parte do diálogo ocorre com a câmera fixa, num plano americano, diante do sacerdote. A cena sugere um plano ponto de vista. O expectador é levado a inquirir o pope da mesma forma que e pelos olhos do oficial alemão. Tal enquadramento dura cerca de um minuto. A permanência nessa posição reforça a ideia de indagação sobre o personagem.

Quando o diretor exibe novamente o pai Pavel, utiliza o travelling para cruzar o templo e se aproximar do sacerdote durante a missa, por sobre o povo, formado por idosos, crianças, jovens e adultos, em direção à cruz sustentada por este. $\mathrm{O}$ mise-en-scène recria um ambiente místico, repleto de ícones e afrescos, enevoado com a fumaça de velas e incenso, repleto tanto de luz quanto de sombras, saturado pelos graves cânticos e orações ortodoxos. O primeiro plano permite perceber a devoção sincera expressa nos rostos. Sua atuação, com persignações, reforça tal ideia. No momento da benção, no qual a audiência beija o crucifixo em suas mãos, pedidos de orações pelo restabelecimento da saúde são interrompidos por uma discreta mensagem junto aos seus ouvidos: o jovem partisan faz o pedido de suprimentos e a localização de sua entrega. Após o suspense em torno de sua verdadeira intenção, o diretor mostra que o pope está engajado com a resistência, utilizando suas aparentes boas relações com os nazistas para espionar ativamente. A benção, pública, durante a missa, constitui uma boa motivação para a cena, que requer proximidade insuspeita. Também sugere a benção da Igreja Ortodoxa para os partisans e a causa do regime, além de uma comunhão estreita entre a instituição religiosa e a população.

Front bez flangov é o primeiro filme de uma trilogia de Gostev, que acompanha os mesmos protagonistas partisans desde as derrotas e os cercos de agosto de 194I até a vitória em Berlim. É sucedido por Front za líniei fronta [Frente atrás da linha da frente], de 1977. É na sacristia de Pavel que informações sobre von Horn são transmitidas e, com a ausência voluntária do sacerdote, ações de sabotagem são planejadas. Os anexos da igreja também servem de hospital para trabalhadores doentes, tratados não pelo padre, mas pelo médico Belyaev (Yuri Tolubeyev). Ambos reconhecem o avanço promovido pelo regime, passando da medicina popular para a moderna. E também que a igreja fora relevada junto com aquela. $\mathrm{O}$ médico e o sacerdote, flagrados socorrendo aos partisans, são presos e executados pelos nazistas. Stalin aparece apenas na segunda parte deste segundo filme da trilogia, algum tempo após o desaparecimento do cura na trama.

Em Duma o Kovpake [A assembleia de Kovpake], a primeira parte da trilogia partisan de Tymofey Levchuk, de 1973, é dentro da igreja, ao abrigo das tropas alemãs circundantes, que os partisans trocam informações enquanto ascendem velas nos

$286 \cdot$ ano XI, n. I6, 2020 • ISSN 2179-5487 
altares. No segundo filme da trilogia, Buran [Energia], um koliadky, coral de crianças, portando estrelas e um bezerro, apresenta-se ao líder partisan Sidor Kovpak (Konstantin Stepankov) cantando antigas músicas natalinas ucranianas.

Em Net neizvestnyh soldat [Não há soldados desconhecidos], 1965, de Sulamita Tsybulnik, é dentro dos templos ortodoxos ucranianos que os soldados feridos encontram proteção, rodeados por enfermeiras, em especial a protagonista, Maria Borovichenko [Natalia Rychagova] - e pelos ícones sagrados.

Religião e nacionalismo podiam fundir-se de maneiras estranhas ao desejo do regime, sem, no entanto, infringi-lo. É o que ocorre em Povest plamennykh let [O conto dos anos de fogo], 1960, da diretora Yuliya Solntseva, com roteiro do célebre Aleksandr Dovjenko, morto quatro anos antes da estreia ${ }^{\text {so }}$ (também é citado nos créditos como produtor). Os homens e mulheres do exército pretendem se casar no solo ucraniano natal, recém-liberado. Afirmam desejar um casamento diferente do convencional praticado antes da guerra. Querem que seja oficial, mas também cerimonioso e “em conformidade com as condições da região”, ou seja, tradicionalista. No auge da campanha antirreligiosa de Khrushchev não há espaço para a celebração por um sacerdote. O general, em trajes civis, o conduz. Russo, nascido no Volga, espanta-se de ganhar afilhados do Dnieper. Seu sermão é secular e recheado de temas patrióticos e de condutas civis e militares caros ao regime. Também não há igreja. A cerimônia ocorre num prédio governamental ainda crivado de balas. A noiva, com grinalda (que retornaria a ser comum no pós-guerra) e trajes típicos, bem como suas acompanhantes, recebe um tema musical inspirado nas canções folclóricas ucranianas e em seu singular coral feminino - no momento do casamento o tema muda. Canta-se a bem mais patriótica e soviética - e não somente ucraniana - Svyashchennaya voyna [Guerra sagrada]. O casal não quebra a taça de cristal, como é comum em casamentos civis. Pelo contrário, bebem o vinho ofertado - cada um em sua taça, e não em uma taça comum a ambos, como no rito ortodoxo. O cuidado da noiva com seu vestido (deseja guardá-lo como recordação para os filhos) e o uso do vinho remetem ao sacramento religioso. Solntseva e Dovjenko eram casados. Produziram juntos, como diretor e codiretora, Shchors (1939). Práticos e conhecedores das regras tácitas das relações entre o cinema e o governo, puderam apresentar temas polêmicos enquanto recitavam parte da cartilha oficial. Ao mesmo tempo, Solntseva conseguiu o tão desejado reconhecimento na área.

50 Seu script original, dos anos 1940, foi rejeitado. Naquele momento, era nacionalista demais para ser aceito (ROLLBERG, P. Historical dictionary of Russian and Soviet cinema. Lanham: Scarecrow Press, 2009, p. 190). No pós-guerra, Stalin desejava filmes que realçassem o esforço bélico de todos os povos soviéticos, ou do povo russo em especial. Não histórias sobre o martírio ucraniano. 


\section{REVISTA ANGELUS NOVUS}

Recebeu o prêmio de Melhor Diretor em Cannes, $196 \mathrm{I}^{5 \mathrm{I}}$. Este não foi o único filme que fundiu religião e nacionalismo ucraniano.

$\mathrm{Na}$ Kiyeuskom napravlenii [Na direção de Kiev], de Vladimir Denisenko, 1967, do estúdio ucraniano Dovjenko, mostra a tentativa de impedir que os nazistas destruam a histórica catedral de Santa Sofia, através da catalogação dos afrescos e mosaicos e sua proteção com sacos de areia. Antes de tudo, eram a "história do povo", e eram mulheres e homens do povo que os protegiam. O diretor exibe frequentemente imagens das igrejas ucranianas. Elas aparecem ao fundo dos cenários abertos, em panorâmicas da destruição causada pelo avanço da guerra, por entre as janelas dos personagens. Maria (Natalia Naum. A protagonista, como em Net neizvestnyh soldat, novamente recebe o nome de Maria e acaba assumindo uma simbologia bíblica), coberta por um véu, e outras mulheres ucranianas, formam uma imagem complementar e sobreposta aos mosaicos. Ela é a guia para os soldados que esperam pelo ataque alemão em Kiev. Lembra-os que as representações de Maria na iconografia eslava baseiam-se em reminiscências pagãs. Que a catedral fora destruída outras vezes e reconstruída. Assim, a imagem religiosa, qualquer que fosse sua origem, simbolizava a resistência e a reconstrução, e a eterna ligação do povo com sua pátria - muito anterior ao milênio cristão. A distribuição de armas ocorre no lado externo da igreja. O simbolismo religioso percorre o filme.

Não foi apenas o cinema ucraniano que inseriu imagens religiosas nos filmes bélicos. O mesmo ocorreu na Bielorrússia. Cherez kladbishche [Através do cemitério], de Victor Turov, foi produzido em 1964, em meio à campanha antirreligiosa de Khrushchev. O diretor utiliza um plano geral, a câmera panorâmica e um lago para refletir um monastério em suas águas. Apesar de não aparecer diretamente, lá está. Algo tão grande que não pode ser oculto, mesmo pela altura do enquadramento, que quase elimina o carroção dos personagens. A religião não é o único tema a ser tratado de maneira pouco sutil na película. $\mathrm{O}$ antigo cemitério da aldeia é repleto de figuras religiosas. Os partisans preparam-se dentro de uma antiga capela. Essa presença religiosa seria um indicativo de sua resiliência entre a população, ou apenas permitiria ao diretor uma melhor ambientação lúgubre para seu filme, sombrio, medonho, complementando o cenário de uma Bielorrússia devastada, com uma trilha sonora (composta por Andrei Volkonsky) que poderia muito bem pertencer a um filme de terror ocidental da mesma década de 1960, como os dos estúdios da Hammer.

Nem sempre a imagem do sacerdote e do religioso foram tão elogiosas no cinema bélico dos anos 1970. Na comédia ambientada durante a guerra Dachnaya poyezdka

SI

Ibid., p. 3 I.

$288 \bullet$ ano XI, n. 16, 2020 • ISSN 2I79-5487 
serjanta Tsybuli [A viagem de turismo do sargento Tsybuli], 1979, de Nikolai Litus e Vitaly Shunko, os dois personagens vinculados à igreja - o diácono (Boris Saburov) e tia Efrosinya (Margarita Krinitsyna), são fofoqueiros e ficam à espreita, preferindo não interagir inicialmente com o sargento do Exército Vermelho (Sergei Ivanov). A primeira cena com o diácono inicia-se com a câmera fechada sobre uma pintura de anjos soando trompas. O que soa em seguida é a campainha do diácono. A câmera se abre e mostra que a gravura pertencia a cabeceira de sua cama. Imediatamente atende Efrosinya e se inteira das novidades na aldeia. A relação do combatente com o religioso é bem menos respeitosa do que entre Mlynski e pai Pavel. Seu encontro ocorre quando Tsybuli o surpreende aparentemente espionando. Apenas o diácono se persigna ao adentrar a igreja. O sargento é devidamente caracterizado como ateu, preferindo se dirigir ao sacerdote como "cidadão". Apesar de indicar um partisan ferido, afirma não poder cuidar dele. Cabe ao sargento leva-lo consigo num carroção, sendo atrasado pelas perguntas do sacerdote. Os religiosos mais atrapalham do que servem a causa da pátria. O mesmo ocorre em Trevojnii mesiats veresen [Mês preocupante ou Mês ansioso das larvas], 1976, de Leonid Osyka. Novamente os personagens religiosos são cômicos e apenas o isbá dos camponeses é repleto de ícones. Constrói-se uma divisão entre um comportamento rural, atrasado, e o urbano, moderno.

Ainda em 1968, o filme ucraniano Annychka, de Boris Ivchenko, acompanhava a vida da jovem de mesmo nome na Rutênia sob controle nazista. Região que até o fim da Segunda Guerra jamais fora incorporada pelos czares ou pela URSS. Todos os camponeses trazem consigo um crucifixo, sejam ricos ou pobres, antifascistas, prófascistas ou colaboracionistas nas milícias. A religião produziria um comportamento fatalista. Os camponeses creditam à vontade divina as ações dos ucranianos que se tornaram policiais auxiliares, Schutzmannschafts's, servindo à ocupação. A cruz, a persignação e o atraso são constantes. A missa é fachada para o flerte do colaboracionista.

A Igreja Ortodoxa Búlgara, muito próxima litúrgica e organizacionalmente da Igreja Ortodoxa Russa, é um caso à parte. Ozerov a exibe em seu Soldaty svobody [Soldados da liberdade]. As interpretações, no entanto, podem ser variadas. Seu sacerdote aparece apenas no momento da execução de líderes comunistas, apoiados pela URSS e igualmente em luta aberta com forças nazistas, pelo regime do czar búlgaro. Os condenados estão diante de um altar, com pão e vinho, segundo a eucaristia ortodoxa. Seria uma relação simpática à Igreja? No entanto, o sacerdote fica postado ao lado dos oficiais czaristas durante a execução. Um elemento que permite uma leitura mais 


\section{REVISTA ANGELUS NOVUS}

aproximada das intenções do diretor, mas não da recepção pelo público, que pode não se ater a detalhes, é que o pão e o vinho permanecem intocados sobre o altar. Os comunistas mantiveram-se alheios aos sacramentos mesmo na hora da morte. No entanto, o regime búlgaro mantinha boas relações com a Igreja. Desde 1953 seus líderes eram escolhidos internamente e não em Constantinopla. A Igreja ainda legitimava ambições búlgaras sobre a Macedônia grega, adepta da religião - o que conferiu ao seu patriarca um título concedido pela Academia Búlgara de Ciências em 1970 \$3. Um dos fatores que promoveram a aproximação entre Stalin e a Igreja Ortodoxa foi a possibilidade de aproximação com os Balcãs oferecida pelo controle das relações entre as igrejas ortodoxas ${ }^{54}$. Ozerov já havia elaborado menções à religião segundo critérios semelhantes em seu Osvobojdenie [Libertação]. Em Ognennaya duga [O arco de fogo], primeira parte de sua pentalogia ou hexalogia, segundo a divisão das tramas, em uma cena não muito distante temporalmente de Goebbels e Churchill citarem a Deus, um comandante soviético de uma unidade de tanques na Frente de Voronej também o faz: "Se acreditasse em Deus, me persignaria". O diretor gostaria de mostrar o oficial se bendizendo antes de entrar em confronto com a avalanche de tanques alemães, mas preferiu inserir uma crítica sútil à censura? Ou demonstra o ateu soviético como moralmente superior aos religiosos e hipócritas líderes da imperialista Inglaterra e da Alemanha fascista?

Nem toda a isbá dos filmes bélicos da década de 1970 possui seu interior recheado com ícones. É o caso de Shel chetvertii god voyny [Foi o quarto ano da guerra], 1983, de Georgiy Nikolaenko. Os soldados do Exército Vermelho se deparam com uma decoração limitada a flores e quadros de família.

O cenário muda com a glasnost. O maior exemplo é Stalingrad, 1989, de Yuri Ozerov. Nele, o general Rodimtsev, em seu diálogo com o velho capitão do Volga (Nikolay Kryuchkov), enquanto cruzam o Volga sob intenso fogo alemão, não usa a terminologia soviética. Prefere o popular "pai” ao chamar o ancião, e não o termo "camarada".

Rodimtsev - Como você está, pai?

Capitão - Como eu poderia estar no final da minha vida? A cada minuto posso passar para a outra vida...

Rodimtsev - O que há em sua mente no final da sua vida? Capitão - Creio que a Rússia [e não União Soviética] tem um destino severo. Há somente dor. E nossa nação é paciente. Tudo o que pode suportar. É uma pena que Deus foi abolido. E sem Deus às vezes é difícil... 
FRANCISCON • "Cinema bélico soviético sobre a Segunda Guerra"

[E ao fim da travessia:]

Capitão - Chegamos, nos entendemos com Deus. Agora, vão!ss

As menções a Deus, presentes em trabalhos anteriores de Ozerov ${ }^{56}$, são mais longas e significativas. Não se tratava de uma ousadia do diretor. O governo Gorbachev havia patrocinado as comemorações dos Iooo anos de cristianismo na Rússia em 1988, ao lado da Igreja Ortodoxa, comandada pelo patriarca Pimen, ou Pemeno. Importantes museus estatais, que no passado foram templos, foram cedidos pelo governo para os festejos, foi cunhada uma moeda comemorativa de 25 rublos, o Bolshoi virou palco para a comemoração e a TV fez a cobertura dos festejos nas principais cidades do país ${ }^{57}$. Sinagogas e, especialmente, mesquitas não receberam os mesmos incentivos que a Igreja Ortodoxa recebeu durante a gestão de Gorbachev. No mesmo ano em que o filme de Ozerov foi terminado, o Papa João Paulo II visitou a URSS, e no ano de seu lançamento, o Vaticano estabeleceu uma embaixada em Moscou.

Ainda na barca, Rodimtsev pede uma canção para distrair a tropa durante a perigosa travessia do Volga. O soldado toca com seu violino uma antiga canção de Odessa, para animar os espíritos - e as almas. A música ao mesmo tempo era um tributo ao multinacionalismo (a influência judaica na música é perceptível, e Odessa possuía mais de $30 \%$ de judeus em sua população) e a religião.

Apesar das referências à religião no filme, Ozerov não mostra o destino de Pavlov, segundo Beevor. O sargento que resistiu por dois meses numa casa teria se tornado arquimandrita da Igreja Ortodoxa ${ }^{8}$. Existiram vários Yakov Pavlov combatendo em Stalingrado ao mesmo tempo. A informação de Beevor não é consensual e não foi utilizada pelo diretor.

\section{Católicos romanos e grego ucranianos}

A Igreja Católica Grega Ucraniana e a Igreja Católica Romana encontravam-se em situação muito diferente da Ortodoxa ao fim da guerra. Além de possuírem um líder fora do território soviético, e em geral hostil aos partidos comunistas, possuíam sua área de abrangência em territórios recém-reincorporados à URSS, como a Lituânia e as

55 STALINGRAD [Stalingrado]. Direção: Yuri Ozerov. Moscou/Hollywood/Praga/Berlim: Mosfilm/Warner Bros./Barrandov/DEFA, 1989. 2 DVDs (196 min), color.

56 Tchuikov (TCHUIKOV, V. A Batalha de Stalingrado. Rio de Janeiro: Civilização Brasileira, 1966, p. 296) afirmava que durante as travessias sob fogo alemão, os comissários faziam seu trabalho de orientação política. Ozerov insere o avesso.

57 TRAGER, Oliver. Gorbachev's glasnost. Nova York: Facts on File, Inc., 1989, p. 68.

58 BEEVOR, Antony. A Segunda Guerra Mundial. Rio de Janeiro: Record, 2015, p. 231. 


\section{REVISTA ANGELUS NOVUS}

regiões da Ucrânia e Bielorrússia ocidentais, ou que jamais estiveram sob controle de um Estado russo, apesar de povoadas por eslavos, como a Rutênia. O regime considerava o clero católico como apoiador da ocupação nazista ${ }^{59}$. O pós-guerra foi um período de repressão e não de liberalização. As tensões com o Vaticano ao logo da Guerra Fria não ajudaram na situação de seus fiéis. Os gregos ucranianos sofriam pressão para trocar a liderança do Papa pela do Patriarca em Moscou. Ainda assim, poucas igrejas ucranianas foram fechadas. Surgiram seminários teológicos secretos em Ternopol e Kolomyia, segundo a imprensa soviética na década de 1960. Em 1974, um convento clandestino foi descoberto em Lvov. Os católicos romanos tiveram suas igrejas reduzidas de 500 para 75 na Letônia, e de I500 sacerdotes na Lituânia, para 735, servindo a 628 igrejas. A repressão, no entanto, não era forte o suficiente para impedir a elaboração de petições ao governo com dezenas de milhares de assinaturas ou que envolvessem boa parte do clero nos anos $1970^{60}$, além do surgimento de samizdat como o Crônica da Igreja Católica Lituana, de tendências políticas liberais ${ }^{6 .}$.

As tentativas do Vaticano de aumentar seus vínculos com as igrejas dentro da esfera de influência soviética eram acompanhadas de perto por agentes do $\mathrm{KGB}^{\mathrm{G}_{2}}$. Apesar de combatida, o regime também desejava obter algum controle sobre a igreja. Entrava em choque com facções antissoviéticas ou suspeitosas e apoiava as que se submetiam formalmente ao Estado e exerciam maior autonomia frente ao Vaticano. O cenário se compunha de diversas correntes e diferentes tratamentos.

Nenhuma outra religião organizada aparece tantas vezes sob uma ótica negativa nos filmes bélicos sobre a Segunda Guerra quanto a Igreja Católica. Tramas envolvendo alianças, espionagem e traição reforçavam as impressões do regime e também as de muitos ortodoxos entre o público. $\mathrm{O}$ anticatolicismo e a desconfiança com relação à Santa Sé eram fenômenos antigos na Rússia. Em Padenie Berlina ${ }^{63}$ [Queda de Berlim],

59 ANDERSON, J. Religion, State and Politics in the Soviet Union and successor States. Cambridge: Cambridge University Press, 1994, p. 166.

60 POSPIELOVSKY, D. Soviet antireligious campaigns and persecutions. Basingstoke: MacMillan Press, I988, pp. I52; 157 .

6I CLAUDIN, F. A oposição ao "socialismo real". Rio de Janeiro: Marco Zero, I983, p. 55.

62 CRUMP, T. Brezhnev and the decline of the Soviet Union. Milton: Routledge, 2013, p. I29.

63 O casamento civil de Hitler, realizado por um notário nazista estacionado na Volksturm, Walter Wagner (FEST, J. Hitler. Rio de Janeiro: Nova Fronteira, 2006), foi transformado numa celebração religiosa por Chiaureli. Um sacerdote (pelo colarinho pode ser católico ou luterano) senta-se à mesa dos futuros mortos. Em Osvobojdenie: Posledniy shturm, Ozerov restitui o caráter civil do casamento. No entanto, insere um sacerdote - claramente luterano - na trama. Soldados nazistas tentam levá-lo para o bunker, mas se recusa a fazer o serviço religioso. É salvo pela ação de um franco-atirador soviético. Apresentado a Tchuikov (Ivan Pereverzev), entra para o comitê antifascista, auxiliando um comunista alemão a pedir por alto-falantes a rendição dos últimos combatentes. Tchuikov o considera um bom sacerdote: "Que o seu deus fale aos soldados alemães, se ainda acreditam". Não possuindo as qualidades realistas de um comunista, mas sim a desvantagem da ingenuidade religiosa, acredita no pedido de rendição, sendo metralhado ao sair ao encontro das tropas. 
FRANCISCON • "Cinema bélico soviético sobre a Segunda Guerra"

o filme icônico do stalinismo, do diretor Mikheil Chiaureli, 1949, o personagem Cesare Orsenigo, Núncio Apostólico (representante diplomático do Papa, Pio XII) na Alemanha entre 1930-45, bajula Hitler ao lado de legatários espanhóis, turcos e japoneses.

Orsenigo - A Santa Sé abençoa e felicita aos heroicos soldados alemães em Moscou, nosso destino está fortemente unido ao seu, meu querido Führer.

Hitler - Querido Pai, aguardo a encíclica do Papa contra os bolcheviques ${ }^{64}$. Dar-me-ia muita satisfação vê-lo no trono sagrado de São Pedro. Vocês são todos nazistas, Orsenigo. Você deveria usar o uniforme das nossas tropas de assalto.

Senhores! Moscou está aos pés da Alemanha!6s

Cardeais do Vaticano apareciam em filmes de espionagem do pós-guerra como agentes imperialistas das grandes potências - e também no cinema propriamente bélico, como Padenie Berlina, onde fazem a corte à Hitler, sem que transpareçam questões espirituais, mas tão somente políticas e materiais. Em Boy posle pobedy [Luta após a vitória], o filme de 1972 que finda a trilogia de Villen Azarov (Put' v Saturn [No caminho da Saturno], 1967, Konets Saturna [O fim da Saturno, 1967])I, um dos agentes infiltrados pelo general Reinhard Gehlen (Mati Klooren) - até então chefe de inteligência da Fremde Heere Ost, e futuro diretor da Bundesnachrichtendienst da Alemanha Ocidental - em sua rede de espiões ex-nazistas, financiados pelos americanos para minar a ocupação soviética na Alemanha Oriental, era um padre bávaro.

Em Front v tylu vraga [Frente atrás das linhas inimigas], I98I, de Igor Gostev, uma coprodução soviética-tchecoslovaca, e o último filme de sua trilogia partisan, a câmera, num plano com grua no sentido obliquo, nos conduz das torres e cruzes, tornando evidente tratar-se de uma igreja católica romanaz, até o lado externo da abside, parcialmente tapada por bandeiras nazistas. Ao pé da igreja, um desfile nazista. Praga possui locações mais reconhecíveis e interessantes para o público do que o exterior traseiro de uma igreja. Há uma tentativa clara de ligar o catolicismo ao nazismo. A missa, apresentada em termos semelhantes aos de Ozerov em Soldaty svobody, é o local perfeito para o encontro de vários espiões e troca de informações.

64 Em 1937 o Papa Pio XI havia escrito a carta encíclica Divinis Redemptoris sobre o "comunismo ateu". Chiaureli, no entanto, se refere não a uma encíclica, mas a um decreto publicado no Acta Apostolicae Sedis, do Santo Ofício, um ano antes da estreia de Padenie Berlina. Em 1948, o Papa Pio XII decretou a excomunhão dos divulgadores das ideias comunistas, e em 1949, aqueles que o defendessem ou votassem em comunistas ou seus aliados. Assim, a Igreja Católica não apenas fora fascista, mas ainda o era. O desejo passado de Hitler tornara-se concreto no presente. Uma força que se opunha ao progresso social na Europa Ocidental. O encadeamento promovido pelo filme se adequa às críticas do regime que relacionava seus inimigos atuais com os recém-derrotados.

65 PADENIE Berlina [A queda de Berlim]. Direção: Mikheil Chiaureli. Moscou: Mosfilm, 1950. 2 DVDs (I51 min), color. 


\section{REVISTA ANGELUS NOVUS}

A exceção se encontra em Soldaty svobody, de Ozerov. Como a Igreja Ortodoxa, a Igreja Católica também é inserida em episódios benéficos ou negativos. O partisan soviético fica preso com seu paraquedas na torre da igreja de uma aldeia eslovaca. $\mathrm{O}$ padre o percebe e pede sua nacionalidade. Ao ser identificado como russo, o sacerdote sobe os degraus da torre. Diante do pedido para ser puxado para dentro, pela janela, o padre soa o sino. O soviético se desespera com a revelação de sua presença: "O que você está fazendo? Você está louco?” A cena é substituída bruscamente pela trama paralela. $\mathrm{O}$ diretor nos faz acreditar que o sacerdote entregou o combatente soviético às autoridades fascistas. O personagem retorna escoltado por vários integrantes $\mathrm{da}$ sociedade eslovaca: soldados, camponeses e o próprio padre: a comunidade toda era antifascista (como o filme deixa claro, a nação eslovaca o era) e esperava ansiosa pela libertação soviética. O soar do sino era um pedido de ajuda ao soviético.

Os comandantes militares envolvidos na rebelião contra o governo fascista clerical3 do Monsenhor Jozef Tiso desfrutam de poder suficiente para com um sinal encerrar a missa destinada a toda a tropa, apresentando-se a tempo na reunião com membros do partido comunista local, em busca de um acordo com os soviéticos. A Igreja não era tão servil ao regime. Desfrutava de amplos poderes no país. No entanto, Ozerov acentua a relação de subjugação ao apresentar um letreiro da Bayer por trás do sacerdote - não seria apenas diante dos militares eslovacos que a instituição se prostraria. O diretor estabelece uma diferenciação clara entre o baixo clero e o padre antifascista e o altoclero, lacaio de Tiso. Desta forma, a Proclamação da República e sua adesão ao campo aliado por parte dos rebeldes pode ser saudada com os sinos dos campanários das igrejas.

Já na Hungria, a ação se passa na catedral de Mátyás, guarnecida pelas tropas fascistas de Miklós Horthy. Apesar de revitalizada pelo governo socialista húngaro poucos anos antes das filmagens para Soldaty svobody, o ambiente é tão escuro e tétrico quanto as figuras que se encontram nela: a cúpula do governo fascista. Impera a pompa vazia - e os pedidos de donativos durante a coleta.

O espírito católico da população polonesa da época sofre uma releitura por Ozerov. As multidões nas ruas, com suas flores sucedâneas de palmas, ajoelham-se não perante o sacrário, mas sim ao desfile das tropas combinadas do Armia Ludowa, Exército do Povo (que combatia clandestinamente na Polônia) e do Ludowe Wojsko Polskie, Exército Popular da Polônia (que, sob Berling, lutava ao lado dos soviéticos), que cortam as ruas de Lublin com igrejas barrocas ao fundo. $\mathrm{Na}$ mesma cidade, e no mesmo 22 de julho de 19444, o Krajowa Rada Narodowa, KRN, Conselho Nacional do Estado, foi reconhecido por Stalin como o governo legítimo do país. O surgimento e 
entronização do exército e do governo pró-soviéticos, rivais do exército e governo próbritânicos, são sacralizados pelo diretor, que emprega os sentimentos populares religiosos e militares profundamente arraigados. A multidão ganha ainda mais os contornos de uma procissão na subida do monte do castelo de Lublin, onde os nazistas, antes de se retirarem, mataram os prisioneiros poloneses. Uma missa campal tem lugar, com seu altar e a imagem da Virgem Negra de Częstochowa. O funeral religioso é interrompido pelo presidente do KRN, Bolesław Bierut (interpretado pelo ator polonês Ignacy Gogolewski). Este começa a cantar Mazurek Dąbrowskiego [A mazurca de Dabrowski], o hino nacional polonêss, sendo seguido por toda a aglomeração. A câmera, num panorâmico horizontal abandona Bierut para focar a bandeira vermelho $\mathrm{e}$ branca, e num travelling vertical, a acompanha por sobre o castelo de Lublin, enquanto o canto popular chega aos céus. É o partido que consegue reerguer os poloneses diante da dor da perda de seus entes queridos, através de uma motivação nacionalista. O governo de coalizão, encabeçado pelo Partido dos Trabalhadores Polacos, recebe ligações tanto com uma Igreja Católica desprovida de fausto, quanto com um mandato celeste. O governo polaco buscava aumentar sua legitimidade - e até sua coesão interna - após as greves de dezembro de 1970 e de junho de 19766 - um ano antes do lançamento de Soldaty svobody.

Em Karpaty, Karpaty [Os Cárpatos, os Cárpatos], última parte de Duma o Kovpake [A assembleia de Kovpake], a trilogia de Tymofey Levchuk, de 1976, os soldados de Kovpak encontram abrigo e alimentação na sacristia de um simples pároco polonês. Ele concede informações sobre as forças alemãs na região aos soviéticos. Dá ordens aos seus sacristãos, que se comportam militarmente. Os convidados mencionam o nível de disciplina que o sacerdote impõe. Ele revela que também é um coronel do Armia Ludowa, terminando a cena com um brinde pela amizade entre os povos soviéticos e os poloneses. Levchuk aproxima a Igreja polonesa da resistência dos grupos de esquerda.

A eleição do Papa João Paulo II, em 1978, colocou a diplomacia soviética em uma situação difícil. As relações com a Igreja Católica melhoraram desde o Concílio Vaticano II (196I-65). Os soviéticos classificavam as alas progressistas da Igreja, como a Teologia da Libertação, como parte da esquerda política dos países não-socialistas. Não era com maus olhos que o Kremlin observava movimentos vinculados a setores católicos lutarem contra a dominação cultural - e na América Central, também econômica -, da potência inimiga na região que esta considerava seu próprio quintal. A eleição de um Papa conservador que combatia os setores considerados progressistas em benefício de sua própria ala, criou um racha interno que, em El Salvador e na Nicarágua desaguou 


\section{REVISTA ANGELUS NOVUS}

em guerra civil entre os dois blocos7. A URSS se viu compelida a continuar a se aproximar da Igreja ao mesmo tempo que resistia contra suas ações no satélite polonês e em outras áreas de população católica sob influência soviética.

U opasnoy tcherti [Fronteira perigosa], 1983, de Viktor Georgiyev, traz o organista Glinsky (Alexander Grave) como um dos líderes do grupo de resistência antinazista. É ele quem informa os agentes soviéticos da produção de Zyklon B com a intenção de lançá-lo contra o Exército Vermelho após testá-lo contra soviéticos nos campos de concentração. Sente que é seu dever informar o mundo dos planos de Hitler para uma guerra química como forma de se evitar represálias contra a Alemanha. Quando a Gestapo invade a escura igreja para prendê-lo, apesar dos olhares dos fiéis, coral e sacerdote, ninguém se move para defender o organista.

Em Stalingrad, 1989, Ozerov apresenta católicos belgas: reacionários e hipócritas talvez em relação com sua base material, a pequena burguesia composta nesse caso por comerciantes de tecidos. Porém, é mais provável pensar em um renascimento do confronto religioso entre católicos romanos e ortodoxos.

Em Nikto ne khotel umirat/Niekas nenorejo mirti [Ninguém queria morrer], de 1966 (novamente logo após a campanha de Khrushchev), de Vytautas Žalakevičius aparece por duas vezes (uma no encerramento) um pequeno oratório em madeira com santos esculpidos debaixo das árvores. Esta última aparição, em meio à penumbra das árvores antes utilizadas como esconderijo pelos guerrilheiros nacionalistas "irmãos da floresta” significaria um elo negativo entre nacionalismo e religião? Um grotão sombrio que permanece apesar do progressismo soviético? Ou seria neutra, acompanhando os personagens? Se o filme dos anos 1960 pode sugerir uma visão negativa, o dos anos 1980 invertem a situação. Outra menção ao catolicismo ocorre já no ambiente da glasnost, no filme Voskresnii den v adu [Um domingo no inferno], 1987, também de Vytautas Žalakevičius. O filme lituano apresenta o coprotagonista, originário desta república, como católico, rezando em latim nas cenas iniciais. O lituano e seu conhecimento do idioma do inimigo tornam-se um importante fator para a sobrevivência do russo entre os alemães. Dependência mútua ao invés do crescente sentimento nacionalista $\mathrm{e}$ secessionista8. A religião do inimigo nazista também aparece, mas na forma luterana e não católica. O diretor possuía sentimentos contraditórios. Membro do partido desde I96I, produziu filmes completamente alinhados politicamente, como sua trilogia sobre um golpe que implanta uma ditadura militar terrorista num fictício país latinoamericano, facilmente identificado com o Chile contemporâneog.

O catolicismo é visto como uma religião externa ao mundo soviético. Não necessariamente negativo no âmbito dos países aliados da Europa Oriental e Central.

$296 \cdot$ ano XI, n. 16, 2020 • ISSN 2179-5487 
Tudo dependia da facção a qual o clero ou o fiel pertencia, se progressista ou conservadora. Mas certamente dotado desta característica em áreas sob influência política inimiga. Personagens católicos podem ser poloneses, tchecoslovacos, alemães do sul, mas jamais ucranianos ou lituanos. O catolicismo não é necessariamente uma força negativa no território dos aliados da União Soviética, mas se torna quando diretamente relacionado com o país, como espiões e conspiradores estrangeiros. A única exceção ocorre no cinema da república lituana, de maneira ambígua na década de 1960 e positiva na de 1980. Já a Igreja Ortodoxa ou seus princípios possuíam defensores e acusadores, com um importante incremento dos primeiros na década de 1970. Seus simpatizantes a exibiam como elemento aglutinador, profundamente ligado (ou mesmo indissociável) ao tradicional nacionalismo russo. Visões positivas e negativas da religião ortodoxa conviveram durante todo o período. No entanto, prevaleceram: I) posições positivas, ligadas à resistência passiva ou ativa ao oponente externo durante o período da concordata stalinista após o conflito (a menção a Deus no filme de Stolper certamente não é uma crítica e não há outras menções de qualquer espécie à religião); 2) negativas ou dúbias durante a campanha irreligiosa de Khrushchev (que se, por um lado, ampliou a laicização social, por outro, mostrou-se incapaz de suprimir a religião, por mais que o desejasse e atuasse por meio da propaganda e do fechamento de templos), pondo em dúvida o auxílio da religião para a vitória na Grande Guerra Patriótica; 3) novamente positivas durante a Estagnação de Brejnev nos anos 1970, compondo um elemento da identidade russa ou eslava, ou mesmo de chauvinismo, em contraste com o inimigo fascista e ocidental; 4) o mesmo se repete mais intensamente durante a perestroika nos anos 1980, marcada agora pelo renascimento da militância religiosa, dos choques étnicos e dos nacionalismos separatistas, com a retirada das ações do partido e do Estado no sentido de procurar guiar a sociedade, quando as facções dos períodos anteriores se esfacelam politicamente.

\section{Fontes}

A ascensão [Voskhojdeniie]. Direção: Larisa Shepitko. Moscou: Mosfilm/Trete Tvorcheskoe Obedinenie, 1977. I DVD (III min), P\&B.

A história de um homem de verdade [Povest o nastoyashchem tcheloveke]. Direção: Aleksandr Stolper. Moscou: Mosfilm, 1948. I DVD (88 min), P\&B.

ANNYCHKA. Direção: Boris Ivchenko. Kiev: Dovjenko Kinostudiya, 1968. I DVD (89 min), P\&B. 


\section{REVISTA ANGELUS NOVUS}

BOY posle pobedy [Luta após a vitória]. Direção: Villen Azarov. Moscou: Mosfilm, 1972. 2 DVDs (166 min), P\&B.

CHEREZ kladbishche [Através do cemitério]. Direção: Viktor Turov. Minsk: Belarusfilm, 1964. I $\operatorname{DVD}(82 \mathrm{~min}), \mathrm{P} \& \mathrm{~B}$.

DACHNAYA poyezdka serjanta Tsybuli [A viagem de turismo do sargento Tsybuli]. Direção: Nikolai Litus; Vitaly Shunko. Kiev: Dovjenko Kinostudiya, 1979. I DVD (75 min), color.

DUMA o Kovpake [A Duma em Kovpak]. Direção: Tymofey Levchuk. Kiev: Dovjenko Kinostudiya, 1973-76. 3 DVDs (328 min), color.

FRONT bez flangov [Frente sem flancos]. Direção: Igor Gostev. Moscou: Mosfilm, 1975. 2 DVDs (170 min), color.

FRONT v tylu vraga [Frente atrás das linhas inimigas]. Direção: Igor Gostev. Moscou/Praga: Mosfilm/Filmové studio Barrandov, 1981. 2 DVDs (I6I min), color.

Front za líniei fronta [Frente atrás da linha da frente]. Direção: Igor Gostev. Moscou: Mosfilm, 1977. 2 DVDs (164 min), color.

NA semi vetrakh [Nos sete ventos]. Direção: Stanislav Rostotskiy. Moscou: Mosfilm/ Pervoe Tvorcheskoe Obedinenie, 1962. I DVD (Io6 min), P\&B.

NET neizvestnyh soldat [Não há soldados desconhecidos]. Direção: Sulamita Tsybulnik. Kiev: Dovjenko Kinostudiya, 1965. I DVD (88 min), P\&B.

NIKTO ne khotel umirat/Niekas nenorejo mirti [Ninguém queria morrer]. Direção: Vytautas Žalakevičius. Vilnus: Litovskaya kinostudiya, 1966. I DVD (Ioo min), P\&B.

O destino de um homem [Sudba tcheloveka]. Direção: Sergey Bondarchuk. Moscou: Mosfilm, 1959. i DVD (IO3 minutos), $\mathrm{P} \& \mathrm{~B}$.

OSVOBOJENIE [Liberação]; Direção: Yuri Ozerov. Moscou: Mosfilm, 1970-7I. 5 DVDs (477 min), color, $\mathrm{P} \& \mathrm{~B}$.

PADENIE Berlina [A queda de Berlim]. Direção: Mikheil Chiaureli. Moscou: Mosfilm, 1950. 2 DVDs (IsI min), color.

SHEL chetvertii god voyny [Foi o quarto ano da guerra]. Direção: Georgi Nikolayenko. Moscou: Gorki Film, 1985. I DVD (85 min), color.

SOLDATY Svobody [Soldados da Liberdade]. Direção: Yuri Ozerov. Moscou/Budapest/Sofia/Berlim/Varsóvia/Praga/Bratislava: Mosfilm/Mafilm/Studiya za igralni filmi Boyana/Deutsche Film (DEFA)/PRF “Zespol Filmowy"/Filmstudio Bucuresti/Filmové studio Barrandov/Slovenská filmová tvorba Koliba, 1977. 4 DVDs (420 min), color.

STALINGRAD [Stalingrado]. Direção: Yuri Ozerov. Moscou/Hollywood/Praga/Berlim: Mosfilm/Warner Bros./Barrandov/DEFA, 1989. 2 DVDs (196 min), color.

$298 \cdot$ ano XI, n. 16, $2020 \cdot$ ISSN 2179-5487 
FRANCISCON • "Cinema bélico soviético sobre a Segunda Guerra"

SUDBA [Destino]. Direção: Evgeny Matveev. Moscou: Mosfilm/Chetvortoye tvorcheskoye obyedineniye, 1977. 2 DVDs (170 min), color.

TREVOJNII mesiats veresen [Mês preocupante ou Mês ansioso das larvas]. Direção: Leonid Osyka. Kiev: Dovjenko Kinostudiya, 1976. I DVD (95 min), color.

TROE sutok posle bessmertiya [Três dias depois da imortalidade]. Direção: Vladimir Dovgan. Kiev: Dovjenko Kinostudiya, 1963. I DVD (85 min), P\&B.

TRYASINA [Lama]. Direção: Grigori Chukhray. Moscou: Mosfilm, 1978. 2 DVDs (I32 min), color.

U opasnoy tcherti [Fronteira perigosa]. Direção: Viktor Georgiyev. Moscou: Mosfilm, 1983. I DVD (94 $\mathrm{min}$ ), color.

V boy idut odni stariki [Apenas os velhos estão indo para a batalha]. Direção: Leonid Bikov. Kiev: Dovjenko Kinostudiya, 1973. I DVD (92 min), P\&B.

VOSKRESNII den v adu [Um domingo no inferno]. Direção: Vitautas Jalakiavichus. Vilnus: Lietuvos kino studija, 1987. I DVD (97 min), color. 
REVISTA ANGELUS NOVUS

\section{Anexos}

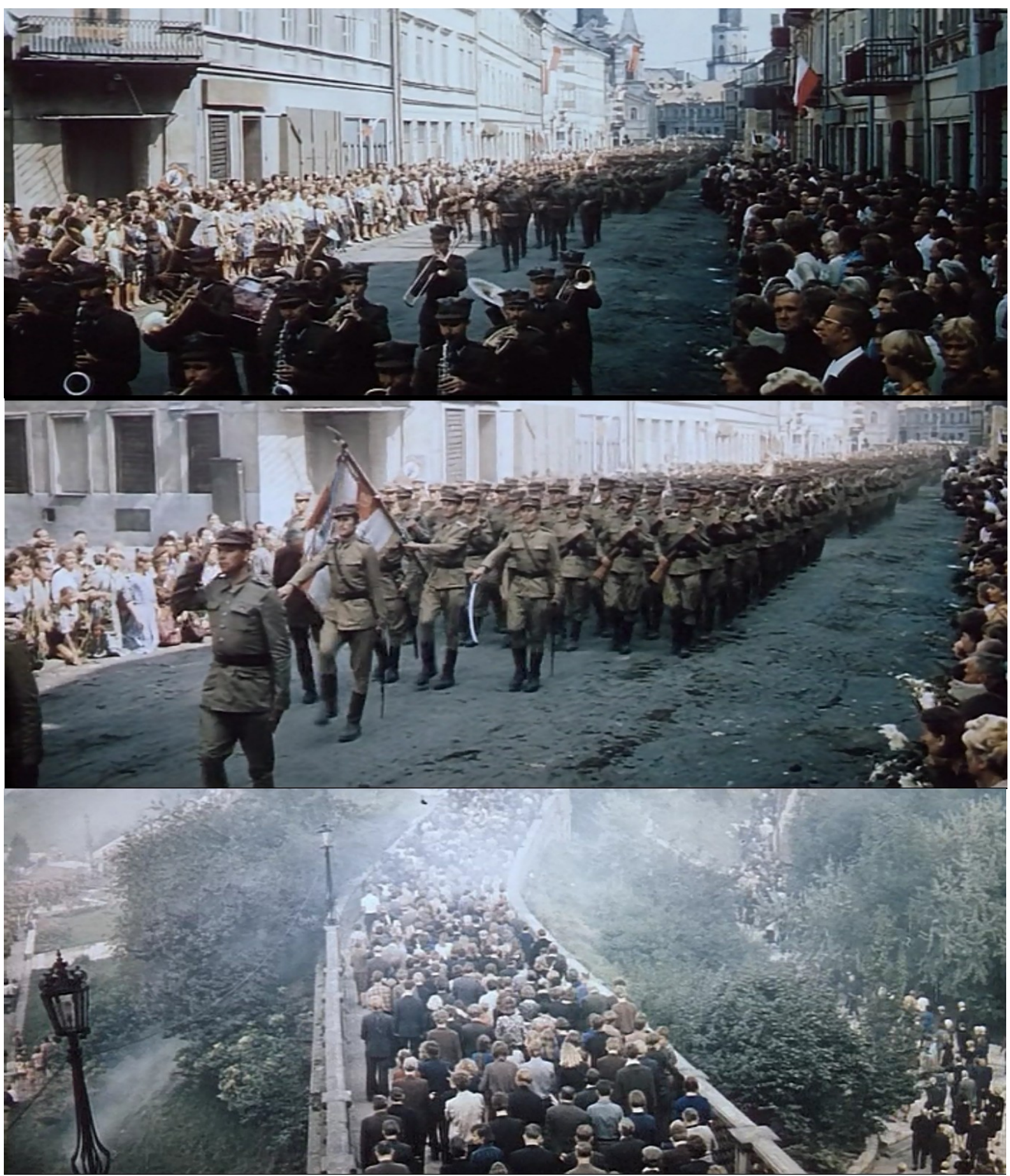

$300 \bullet$ ano XI, n. I6, 2020 • ISSN 2179-5487 
FRANCISCON • "Cinema bélico soviético sobre a Segunda Guerra"

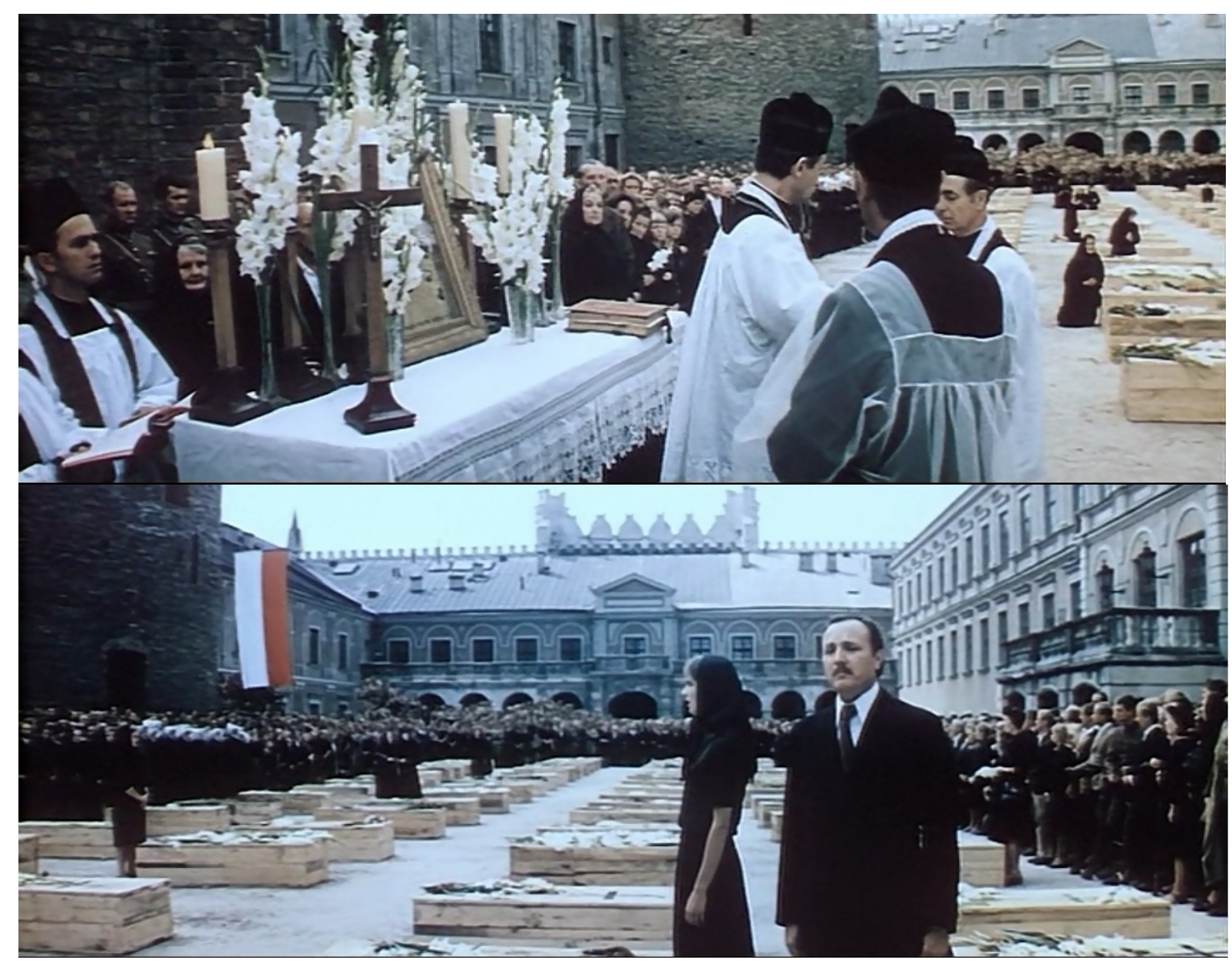

Figura I: O cinema bélico soviético como uma política de boa vizinhança: tropas do Armia Ludowa entram sozinhas em Lublin. A multidão se ajoelha com ramos. O sentimento de procissão religiosa aumenta com a multidão subindo a colina do castelo o diretor utiliza um cenário com névoa e música de fundo religiosa. A Virgem Negra de Częstochowa dá lugar ao líder Bierut e a apoteose patriótica. Soldaty Svobody [Soldados da Liberdade]. Yuri Ozerov, 1977. 
REVISTA ANGELUS NOVUS
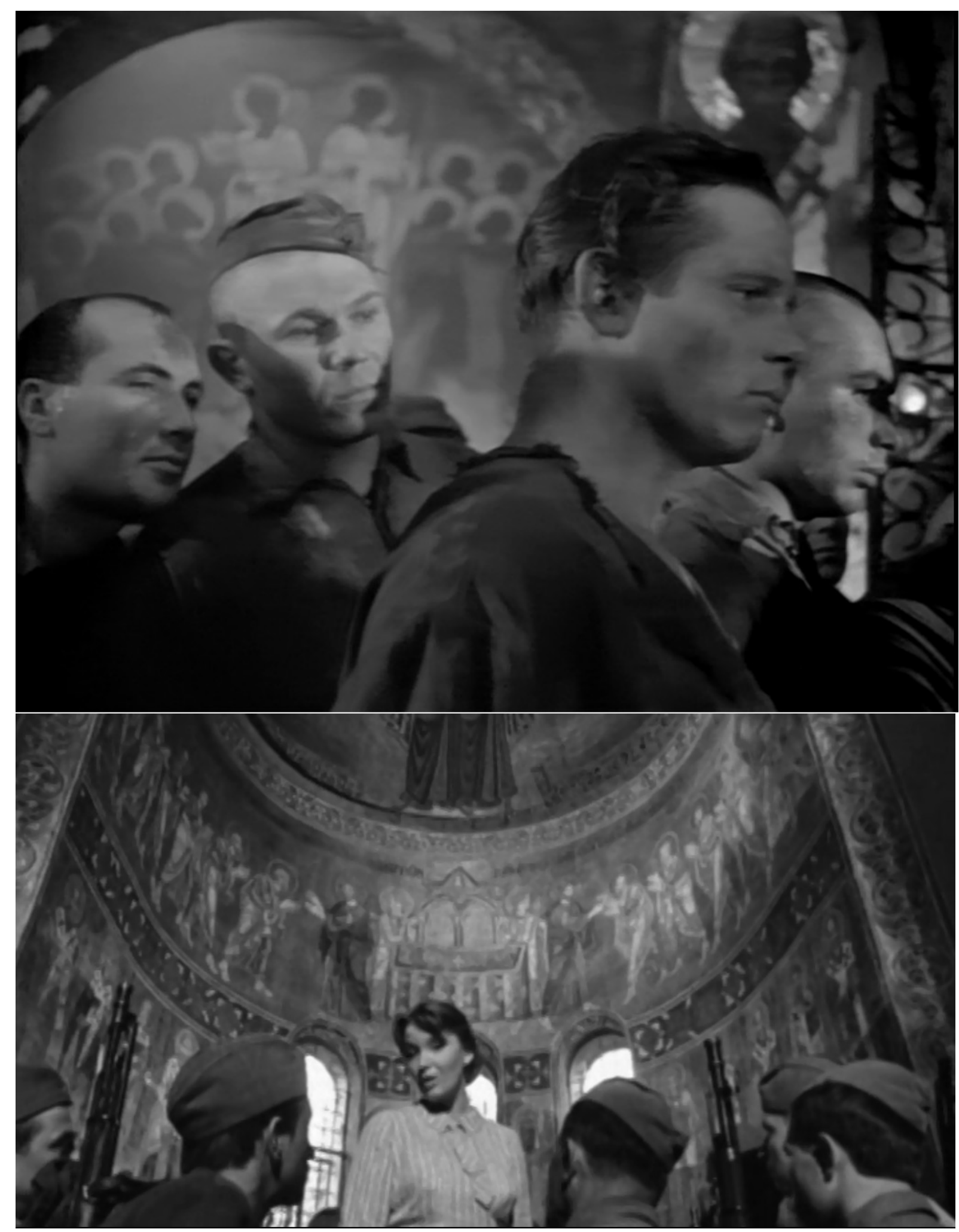

$302 \cdot$ ano XI, n. 16, 2020 • ISSN 2179-5487 
FRANCISCON • "Cinema bélico soviético sobre a Segunda Guerra"

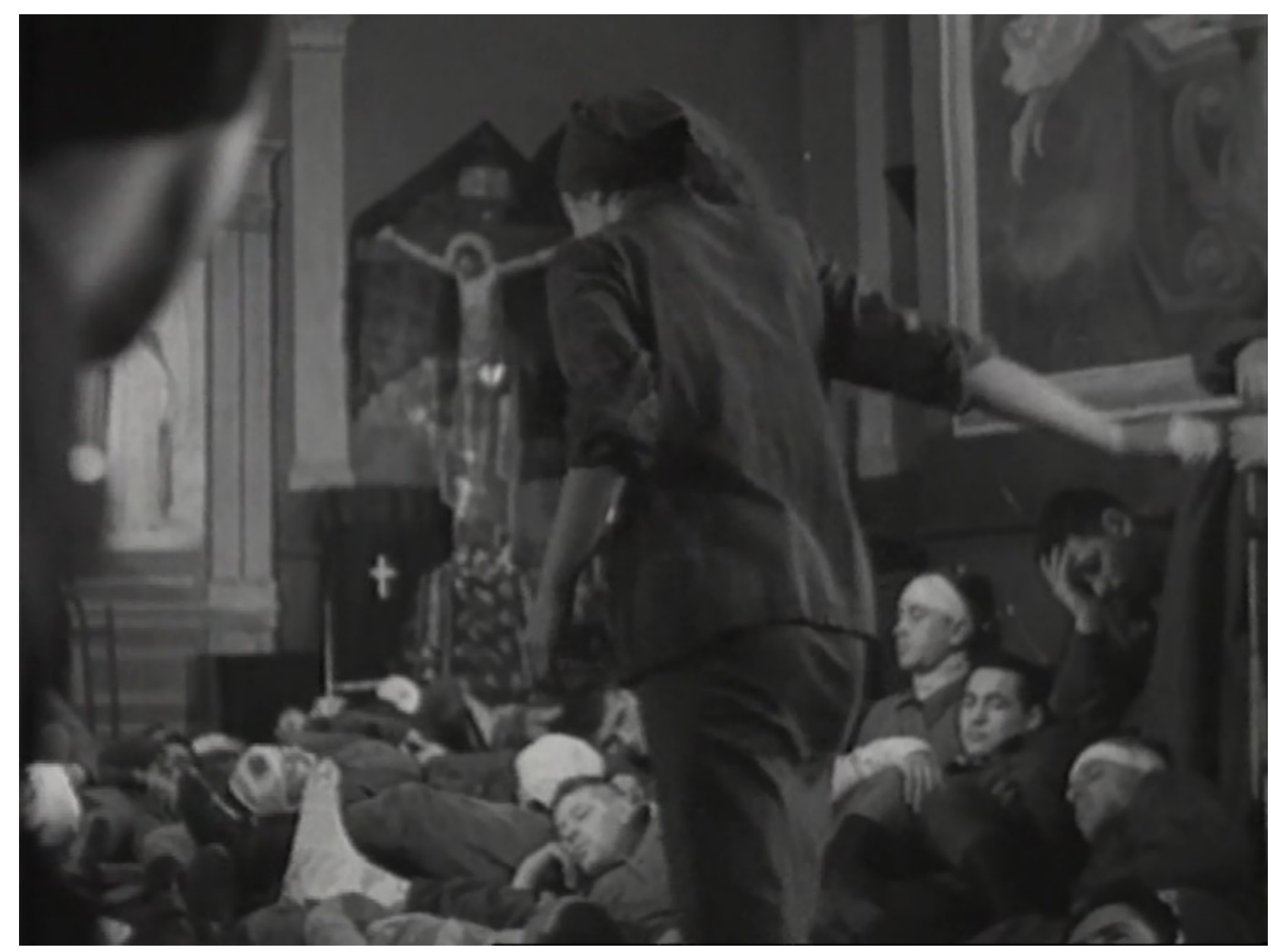

Figura 2: Iconologia com santos: acima, O destino de um homem. Sergey Bondarchuk, 1959; no centro, Na Kiyevskom napravlenii [Na direção de Kiev]. Vladimir Denisenko, 1967 (o diretor aumenta a vinculação entre a enfermeira como maria e os soldados abaixo como santos pelo uso da grua vertical transitando da cúpula com os ícones dourados para baixo); abaixo, Net neizvestnyh soldat [Não há soldados desconhecidos]. Sulamita Tsybulnik, 1965. 


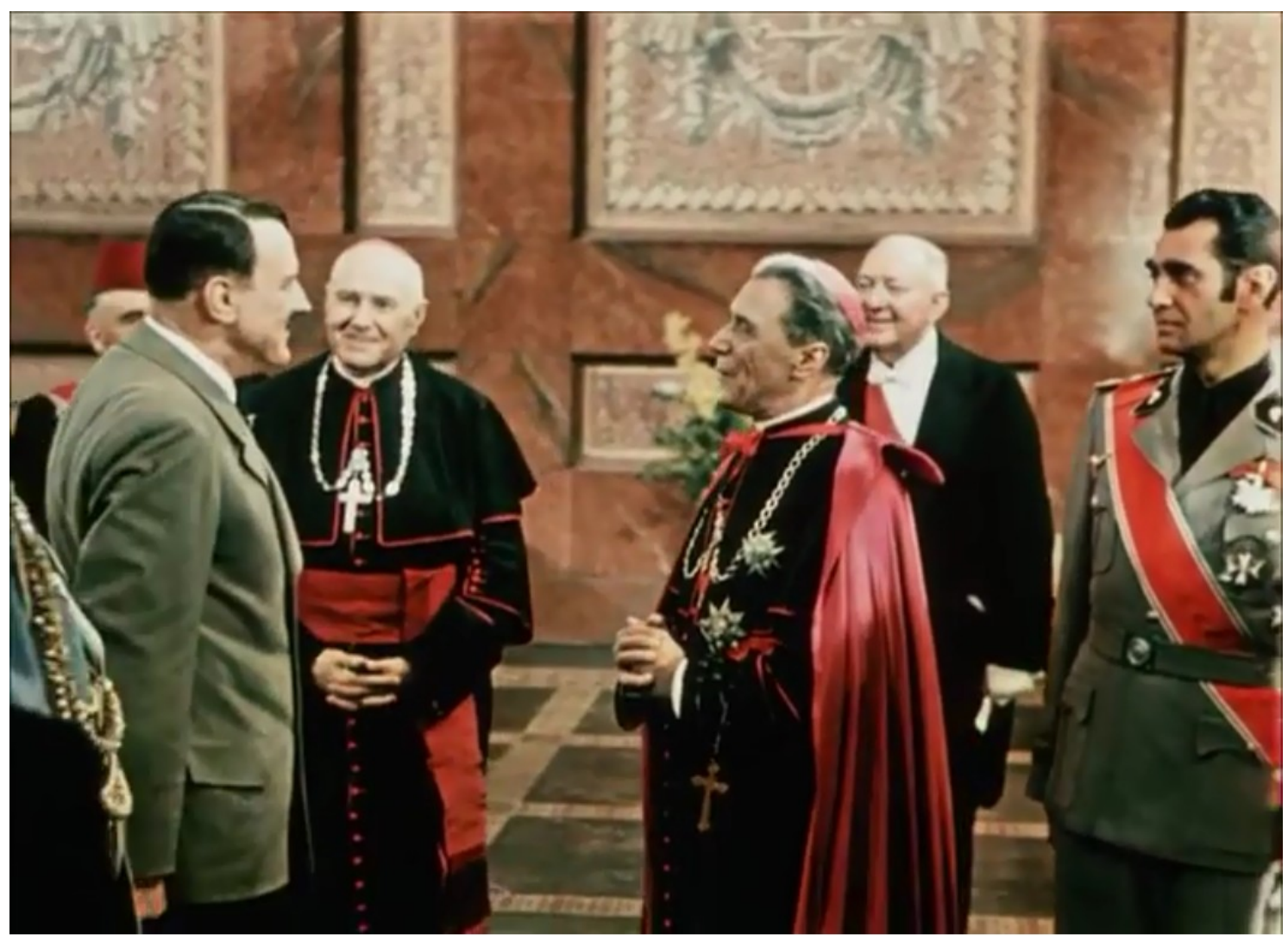

Figura 3: Conde Galeazzo Ciano e o Núncio Apostólico Cesare Orsenigo diante de Hitler. Padenie Berlina [A queda de Berlim]. Mikheil Chiaureli, 1950. 
FRANCISCON • "Cinema bélico soviético sobre a Segunda Guerra"

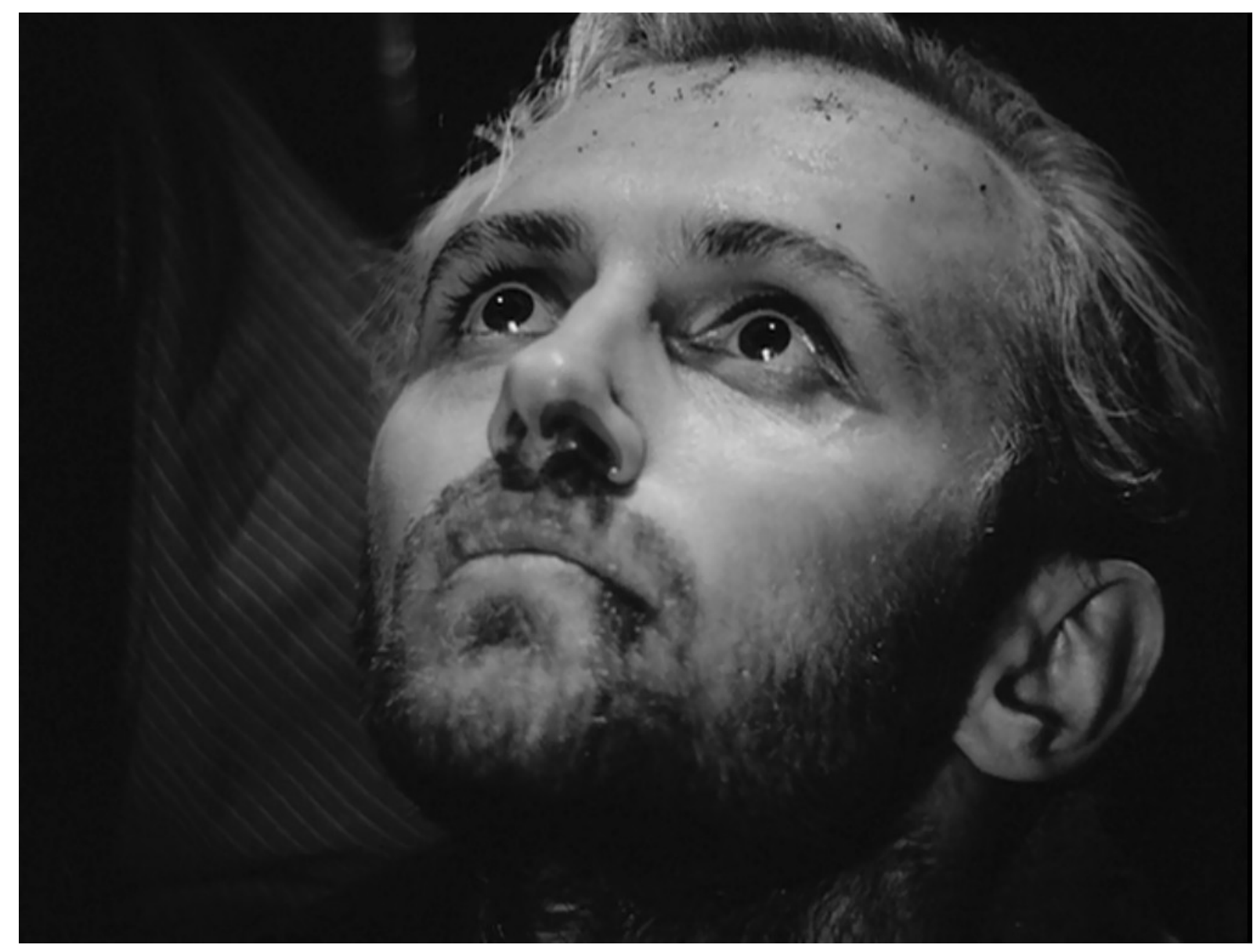

Figura 4: Iconografia sem santos: A ascensão. Larisa Sheptiko, 1977. 
REVISTA ANGELUS NOVUS

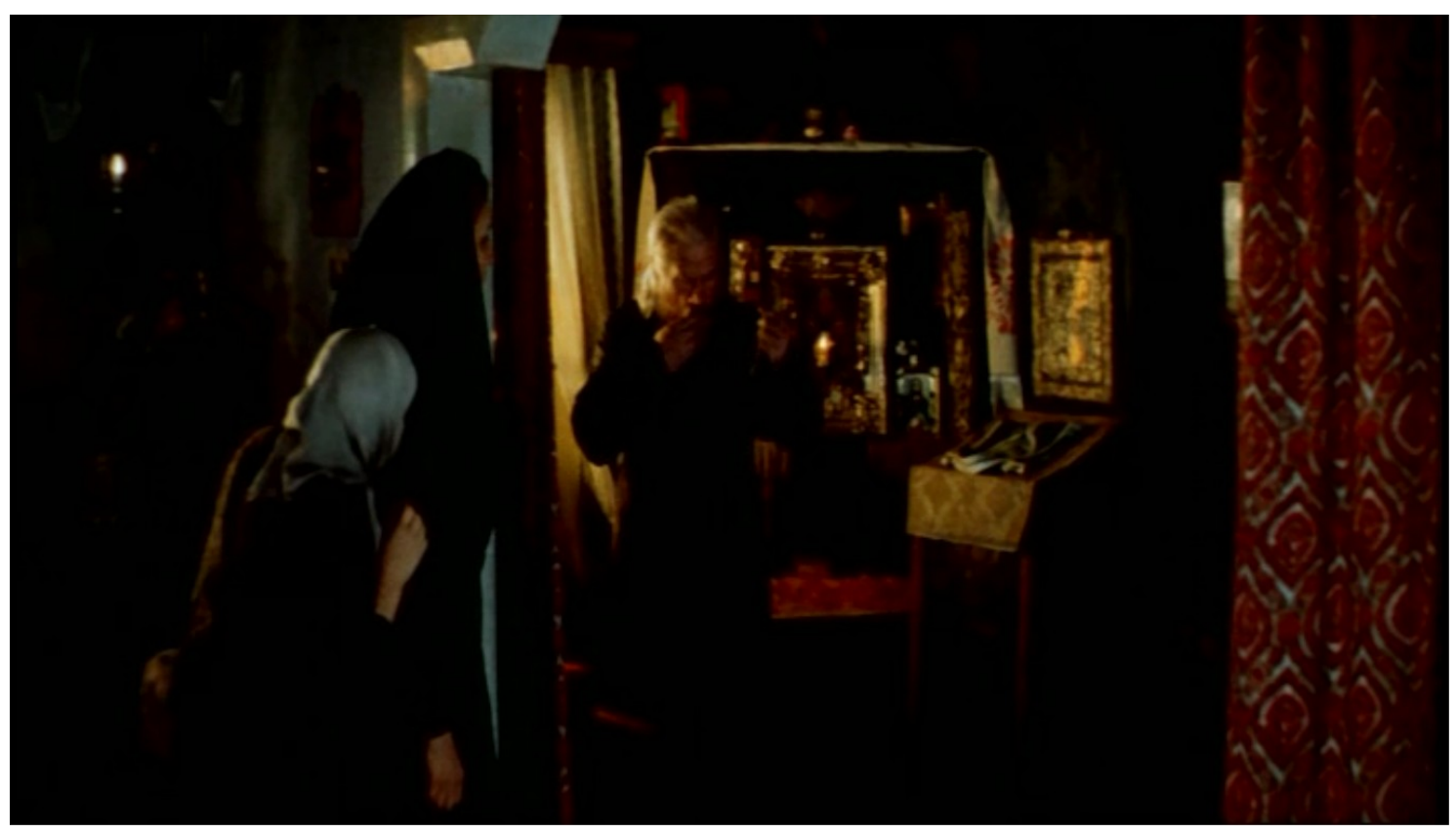

Figura s: O sacerdote patriota. Tryasina [Lama]. Grigori Chukhray, 1978. 
FRANCISCON • "Cinema bélico soviético sobre a Segunda Guerra"

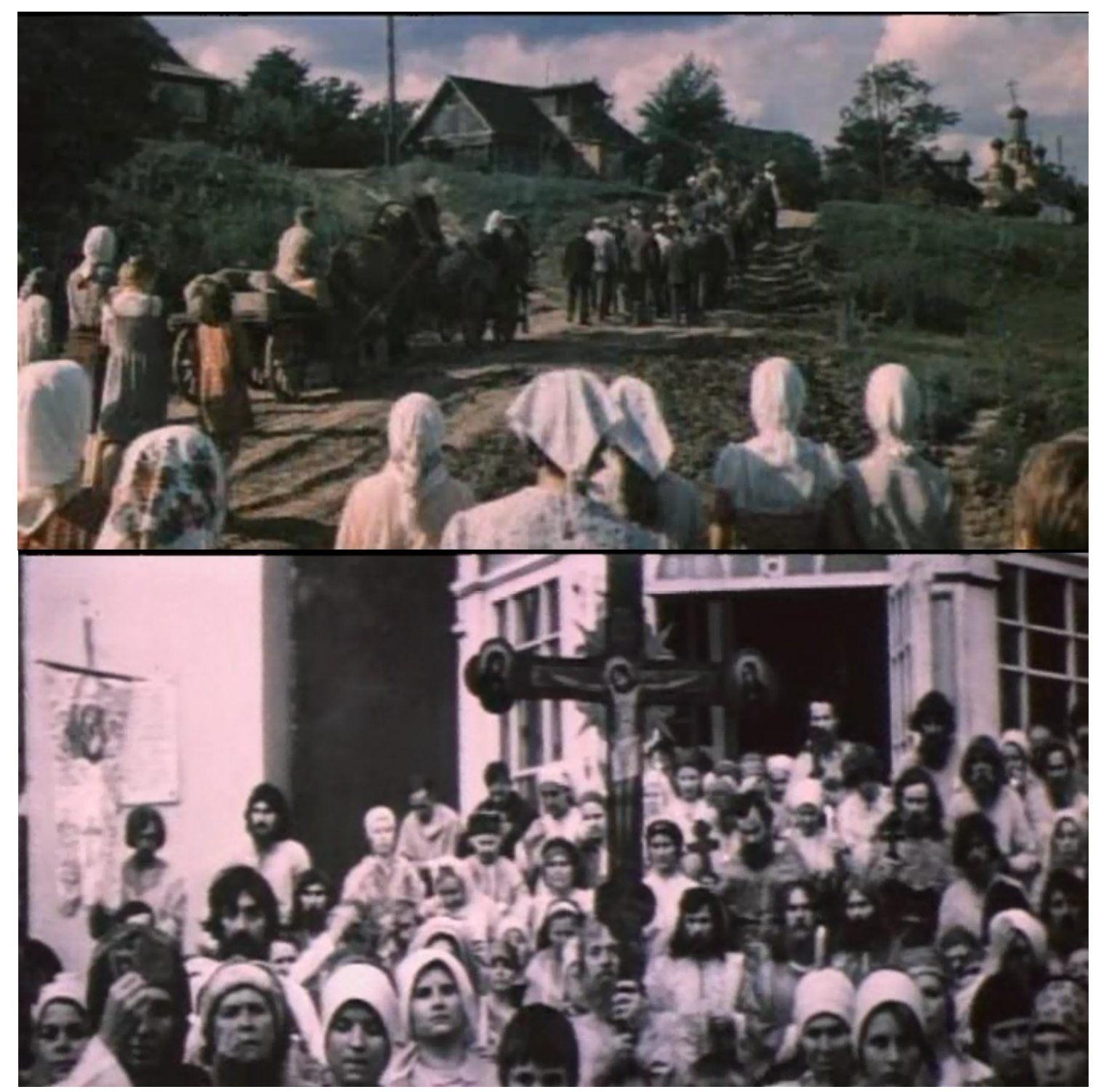

Figura 6: A religião como elo de ligação da identidade russa entre o combatente do passado czarista, o da Grande Guerra Patriótica - e, consequentemente, também o da Guerra Fria, a quem o filme é destinado. Sudba [Destino]. Evgeny Matveev, 1977. 
REVISTA ANGELUS NOVUS

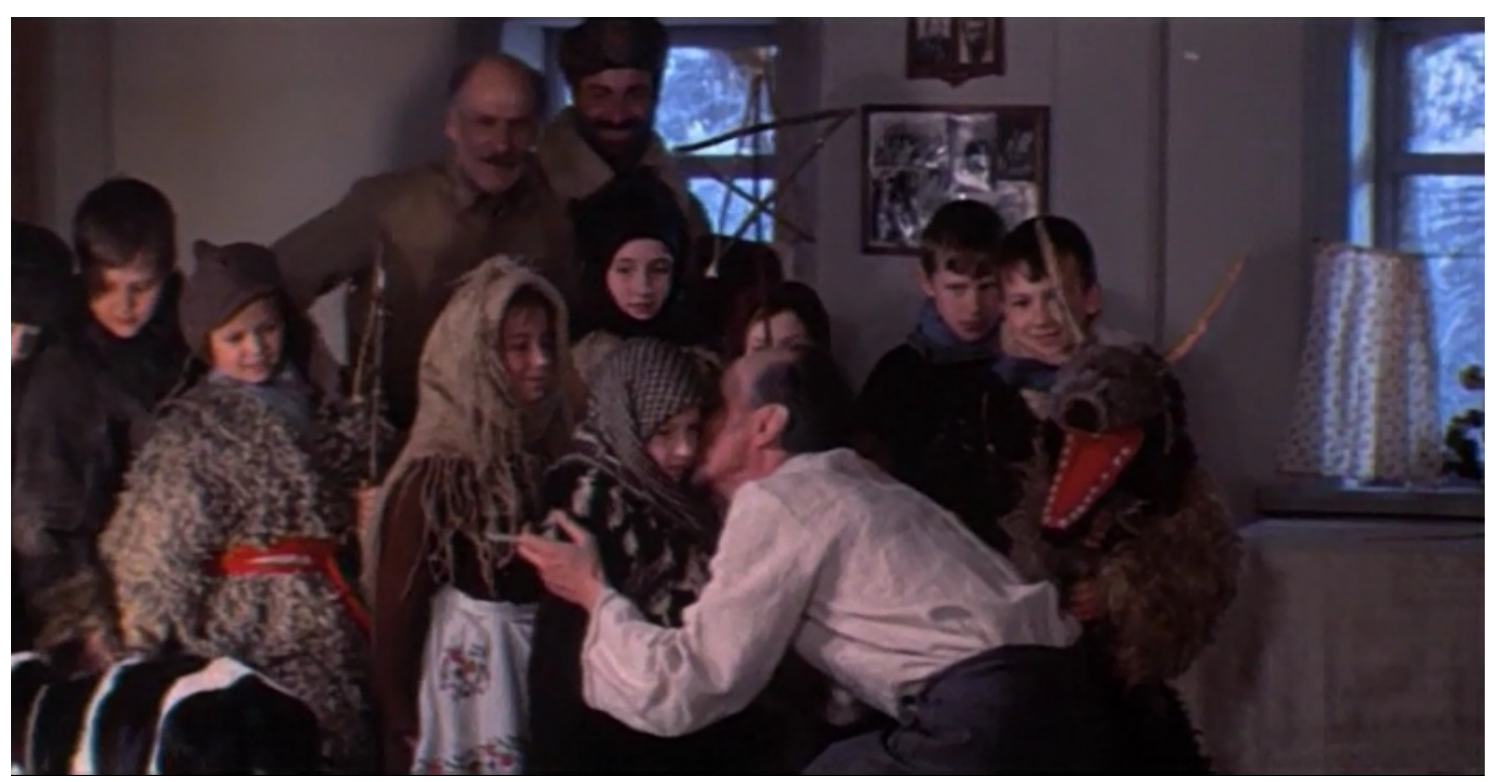

Figura 7: A tradição religiosa das festas natalinas como renascimento do nacionalismo ucraniano. Buran [Energia]. Tymofey Levchuk, 1973. 
FRANCISCON • "Cinema bélico soviético sobre a Segunda Guerra"

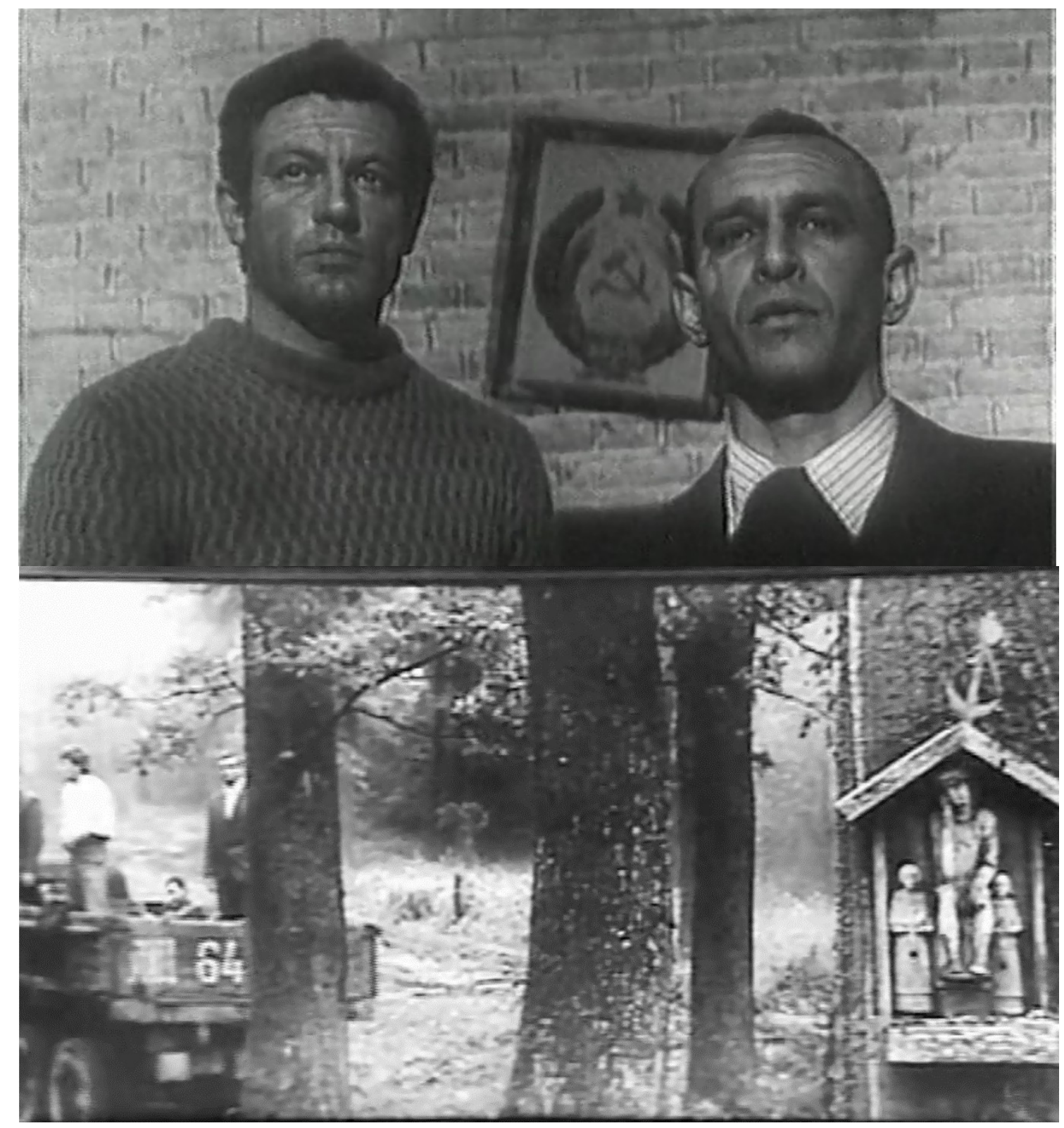

Figura 8: Imagens da devoção lituana ao partido - mas também ao catolicismo romano. Nikto ne khotel umirat/Niekas nenorejo mirti [Ninguém queria morrer]. Vytautas Žalakevičius, 1966. 
REVISTA ANGELUS NOVUS

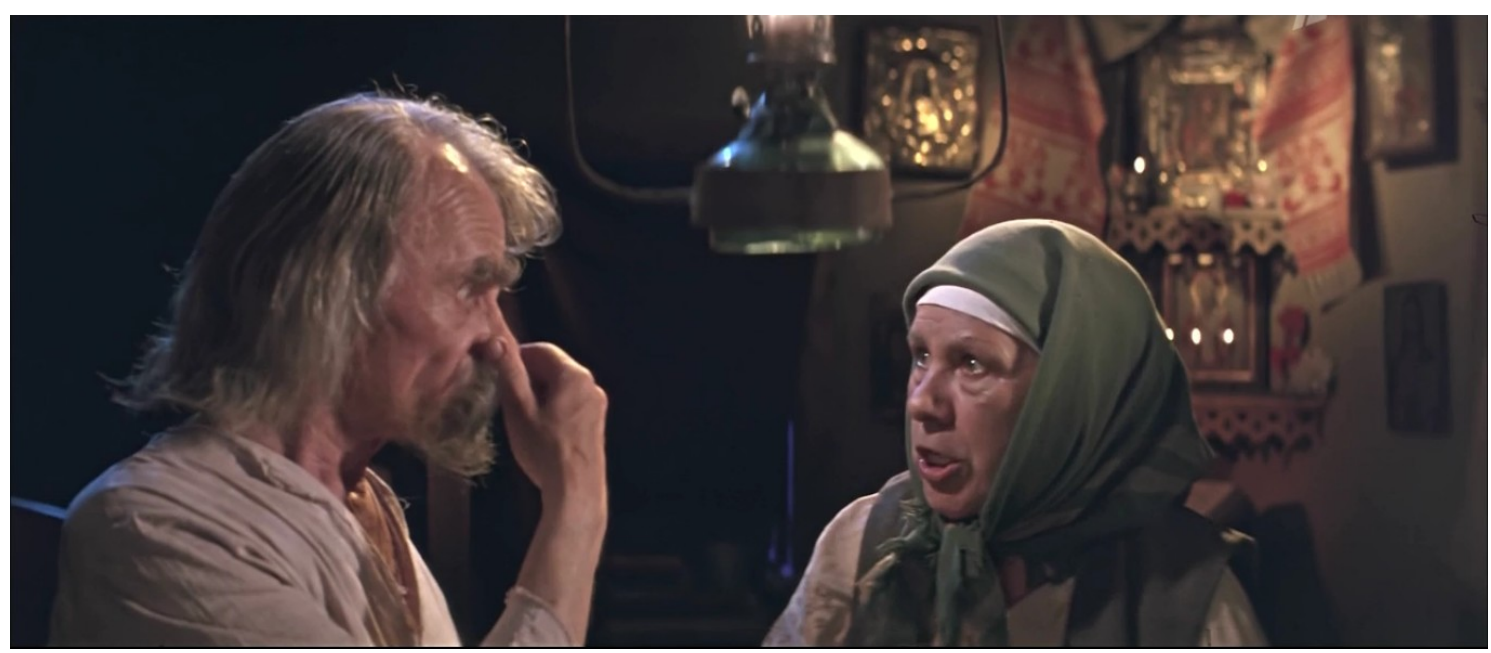

Figura 9: A religião ortodoxa, o sacerdote e os fiéis como material para o humor. Dachnaya poyezdka serjanta Tsybuli [A viagem de turismo do sargento Tsybuli]. Nikolai Litus; Vitaly Shunko, 1979. 
FRANCISCON • "Cinema bélico soviético sobre a Segunda Guerra"

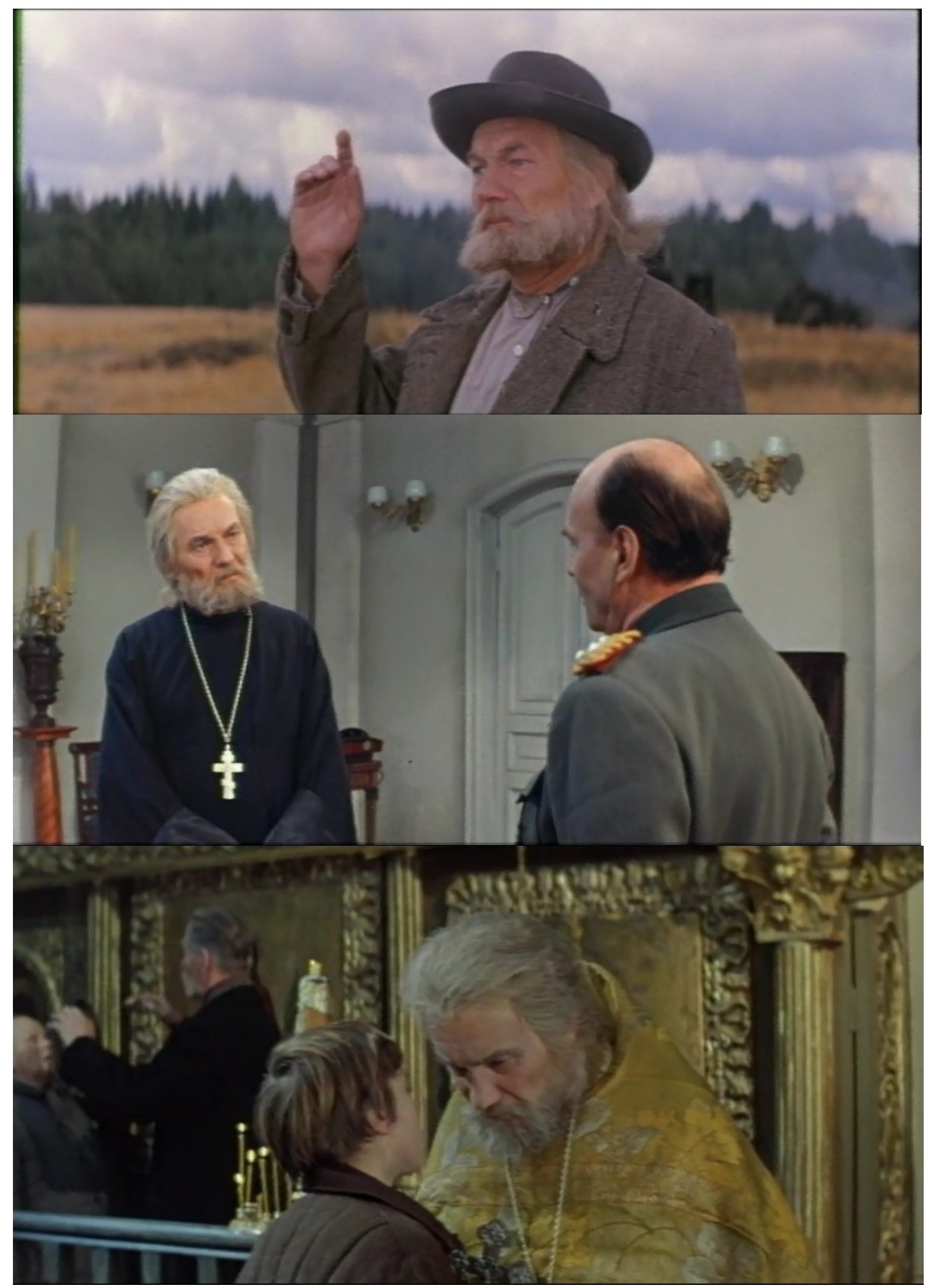

Figura ro: As três caras de pai Pavel. Front bez flangov [Frente sem flancos]. Igor Gostev, 1975 . 
REVISTA ANGELUS NOVUS

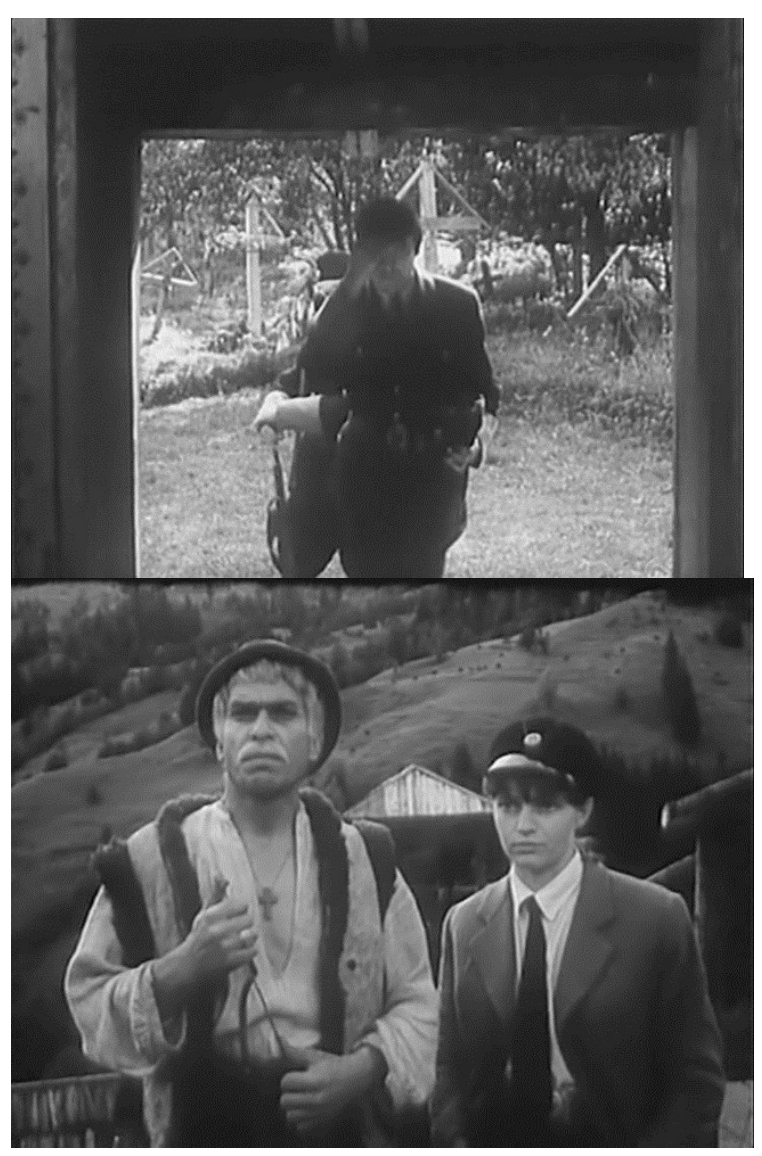

Figura II: ucraniano aliciado pelos nazistas se persigna para entrar na igreja e tentar conquistar a protagonista; kulak colaboracionista assiste à escravização sob os nazis. Annychka. Boris Ivchenko, 1968. 
FRANCISCON • "Cinema bélico soviético sobre a Segunda Guerra"

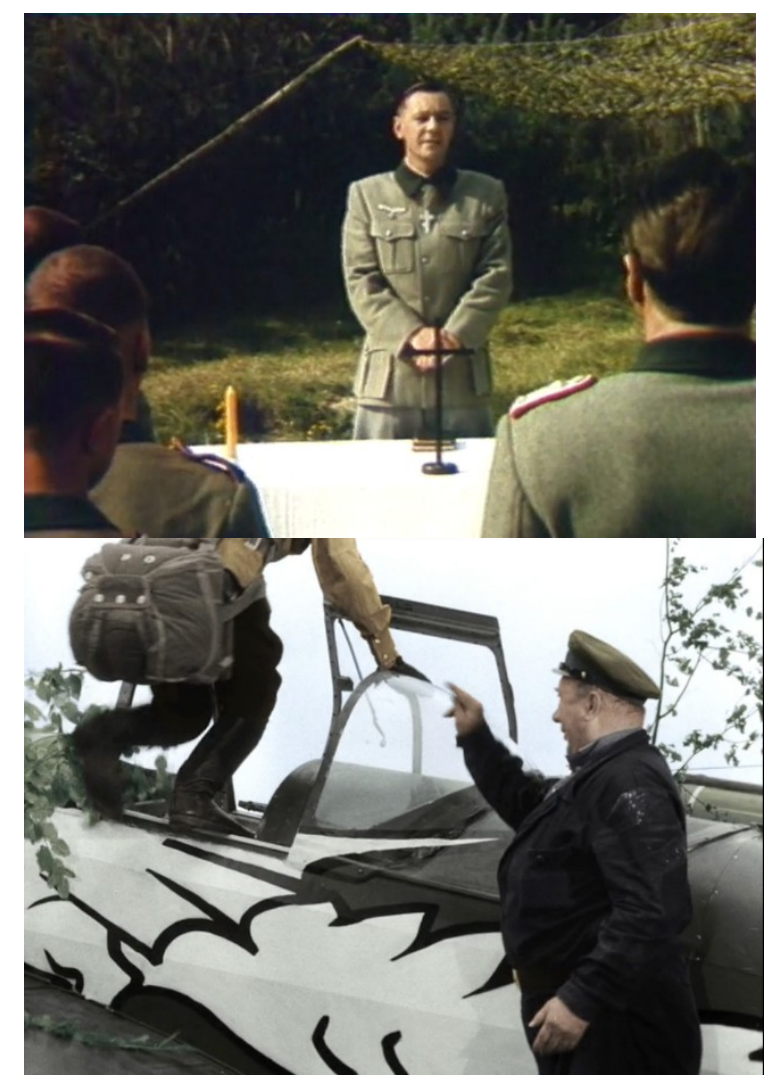

Figura 12: Nazis luteranos. Voskresnii den $\mathrm{v}$ adu [Um domingo no inferno]. Vitautas Jalakiavichus, 1987. "Há muita fofoca no exército de Hitler". V boy idut odni stariki [Apenas os velhos estão indo para a batalha]. Leonid Bikov, 1973. 